\title{
Exploring phosphorus fertilizers and fertilization strategies for improved human and environmental health
}

\author{
Prem S. Bindraban ${ }^{1} \cdot$ Christian O. Dimkpa $^{1} \cdot$ Renu Pandey ${ }^{2}$ \\ Received: 20 February 2019 / Revised: 18 December 2019 / Accepted: 30 December 2019 / Published online: 8 January 2020 \\ (C) The Author(s) 2020
}

\begin{abstract}
Mineral phosphorus (P) fertilizers support high crop yields and contribute to feeding the teeming global population. However, complex edaphic processes cause $P$ to be immobilized in soil, hampering its timely and sufficient availability for uptake by plants. The resultant low use efficiency of current water-soluble P fertilizers creates significant environmental and human health problems. Current practices to increase $\mathrm{P}$ use efficiency have been inadequate to curtail these problems. We advocate for the understanding of plant physiological processes, such as physiological $\mathrm{P}$ requirement, storage of excess $\mathrm{P}$ as phytate, and plant uptake mechanisms, to identify novel ways of designing and delivering $P$ fertilizers to plants for improved uptake. We note the importance and implications of the contrasting role of micronutrients such as zinc and iron in stimulating $P$ availability under low soil P content, while inhibiting P uptake under high P fertilization; this could provide an avenue for managing P for plant use under different $\mathrm{P}$ fertilization regimes. We argue that the improvement of the nutritional value of crops, especially cereals, through reduced phytic acid and increased zinc and iron contents should be among the most important drivers toward the development of innovative fertilizer products and fertilization technologies. In this paper, we present various pathways in support of this argument. Retuning P fertilizer products and application strategies will contribute to fighting hunger and micronutrient deficiencies in humans. Moreover, direct soil P losses will be reduced as a result of improved P absorption by plants.
\end{abstract}

Keywords Innovative phosphorus fertilizers $\cdot$ Zinc-phytate ratio $\cdot$ Human nutrition $\cdot$ Micronutrients $\cdot$ Nutrition-sensitive agriculture

\section{Introduction}

Phosphorus $(\mathrm{P})$ is an essential, non-replaceable nutrient in biology, with finite global reserves. Whereas soils may contain pools of P that could be several thousand times higher than required for plant growth, only a small soluble fraction is available for plant uptake (Smil 2000; Sohrt et al. 2017). This is due to complex edaphic processes and interactions with soil components such as iron and aluminum hydroxides in acidic soils, and calcium in alkaline soils. In addition, humidity, and the

Prem S. Bindraban

pbindraban@ifdc.org

1 International Fertilizer Development Center (IFDC), Muscle Shoals, AL 35662, USA

2 Division of Plant Physiology, ICAR-Indian Agricultural Research Institute, New Delhi 110012, India presence of clay particles also cause $\mathrm{P}$ to be immobilized in soil. Mean average temperature and precipitation are prime determinants of large-scale variability in plant production or annual net primary production, followed by nitrogen $(\mathrm{N})$ and $\mathrm{P}$ (Cleveland et al. 2011). N limitation is more likely to occur in temperate regions and $\mathrm{P}$ limitation in tropical areas, especially on highly weathered soils such as Oxisols and Ultisols that dominate the tropical lowlands (Cleveland et al. 2011). Moreover, increased use of $\mathrm{N}$ fertilizers in agriculture in these regions could contribute in worsening $P$ limitation and increasing $\mathrm{P}$ need of plants, due to alterations in microbial biomass $\mathrm{P}$, and its ratios with microbial biomass $\mathrm{N}$ and $\mathrm{C}$ (Fan et al. 2018). Cleveland et al. (2011) reported foliage and soil $\mathrm{P}$ to be the best predictor for tropical lowland forest annual net primary production with an average of 14.7 and $18.8 \mathrm{tha}^{-1}$ year $^{-1}$ for low and high $\mathrm{P}$ soils, respectively. Annual net primary production of approximately $8 \mathrm{t} \mathrm{ha}^{-1}$ year $^{-1}$ is reported for the Sahelian region of Africa, of which about $3.3 \mathrm{t} \mathrm{ha}^{-1}$ year $^{-1}$ is aboveground biomass (Ardö et al. 2018). Hence, additional mineral fertilizers, including P, must be applied to attain high yields, as 
crop production is often nutrient limited under natural conditions (Breman et al. 2001; Fageria and Oliveira 2014).

Global P fertilizer use has increased from 4.6 million tons in 1961 to approximately 21 million tons in 2015 and contributed to the green revolution and food security. Future global demand assessments estimate 22-27 million tons $\mathrm{P}_{\text {year }}{ }^{-1}$ by 2050 for cropland and an additional 4-12 million tons $\mathrm{P}$ year ${ }^{-1}$ for grassland (Mogollon et al. 2018). Over the past two decades, however, a large body of literature debated that the $P$ reserves might be depleted in about 70 to over 300 years, with a peak P demand around the year 2030 (Cordell et al. 2009; Van Kauwenbergh 2010). Much of the P applied to soil as mineral fertilizers or organic manure is bound to soil, creating a pool of residual $\mathrm{P}$, or is lost via leaching, runoff, and/or erosion and may reach waterbodies, contributing to eutrophication (Conijn et al. 2018). Leaching of P could be exacerbated by depleted soil organic matter due to P-induced alteration in microbial community that alters both microbial activity and C cycling rates (Wakelin et al. 2017). However, when not leached, the surplus $\mathrm{P}$ may be retained by sorption on metal $(\mathrm{Fe}, \mathrm{Al})$ hydroxides, carbonates $(\mathrm{Ca})$, and 1:1 phyllosilicates, or bound to organic matter compounds via cation bridges.

Global surpluses buildup at an estimated 11-16 MT P year $^{-1}$ (Sattari et al. 2012; Bouwman et al. 2017; Lu and Tian 2017) which may become available to crops depending on the amount, distribution and cropping system (Rowe et al. 2016), and by $P$ activators though with highly site-specific effects (Zhu et al. 2018). Excess P in surface waters causes toxic algal blooms and hypoxic conditions that are detrimental to aquatic life in inland water bodies and ultimately contribute to dead coastal zones (Chowdhury et al. 2017). The environmental concerns and debate about "Peak P" have accelerated efforts to maximize $\mathrm{P}$ use efficiency for high crop yield. The environmental impacts of $\mathrm{P}$ could be minimized via multiple mitigation opportunities offered by optimized management and re-use of $\mathrm{P}$ along the entire $\mathrm{P}$ cycle (Chowdhury et al. 2017). These range from technological improvement in mining and production, reducing food waste, recovery and recycling of $\mathrm{P}$ from sewage sludge, manure, offal, and water bodies, to redistribution of $\mathrm{P}$ from regions with high abundance to regions with $\mathrm{P}$ deficiency. Optimized application rates based on prior soil information also stimulate uptake of residual soil $\mathrm{P}$, placement of $\mathrm{P}$, adapted cropping sequence to maximize $\mathrm{P}$ utilization, measures to reduce soil erosion, and discharge to water bodies, like vegetation buffer zones adjacent to streams, are a few of the possible mitigation measures to reduce emissions. These fertilization technologies and agronomic practices have been implemented already for several decades in some parts of the world to enhance $P$ use efficiency. However, these have been unable to cut back P losses within the limits of the planetary boundaries (Rockström et al. 2009); defined as limits for the safe operating space for humanity beyond which deleterious or even catastrophic events will trigger non-linear, abrupt environmental change within continental- to planetary-scale systems. This is true for $\mathrm{N}$ as well (Conijn et al. 2018). Thus, despite efforts to mitigate $P$ losses, only $20-25 \%$ of primary $\mathrm{P}$ applied as fertilizer ends up in consumed food, which indicates significant $P$ leaks in the food system (Van Dijk et al. 2016).

For these reasons, Bindraban et al. (2015) called for a paradigm shift in nutrient-fertilizer design, packaging, and delivery to plants through pursuing a better understanding of plant physiological processes that drive nutrient uptake and utilization. It is hypothesized that a better understanding of the physiological mechanisms of $\mathrm{P}$ uptake by root and foliage, impact on photosynthesis, translocation to grains, synthesis of plant metabolites, and interaction with other nutrients will provide insights for developing alternative and more efficient fertilizer products and application technologies to optimally meet the biotic needs for P (Noack et al. 2010; Pandey et al. 2013; Withers et al. 2014). Novel approaches for packaging P, including bio- and bio-nano-chemistry, hybrid $\mathrm{P}$ formulations of water-soluble $\mathrm{P}$ with phosphate rock, and phosphate rock formulations with organic acids or microorganisms are described in this paper. These approaches have the potential to fine-tune P supply to plants' metabolic processes, allowing for lower amounts of $\mathrm{P}$ to be used in fertilizers. These novel products may allow nutrient delivery through all organs such as roots, leaves, and stems, with the potential to reduce the amount of metabolically inactive or counteractive P stored in plant tissues. Moreover, improving the nutritional value of crops to better meet human dietary needs beyond calories could drive P-based fertilizer design and delivery as well (Bindraban et al. 2018). In this paper, we review potential pathways to arrive at innovative $\mathrm{P}$ fertilizer products and fertilization strategies to increase crop P use efficiency, thereby enhancing productivity and crop nutritional value.

\section{Impact of P on crop growth, yield, and nutritional quality}

The relationship between leaf $\mathrm{P}$ and $\mathrm{N}$ is particularly critical, given that both elements are essential for photosynthesis and plant development. Reich et al. (2010) provided evidence for a stoichiometric relationship between $\mathrm{N}$ and $\mathrm{P}$ leaf concentration for major plant groups that underpins the linkages of fundamental metabolic growth processes. Photosynthesis is primarily determined by leaf $\mathrm{N}$ content, but at lower $\mathrm{P}$ concentrations, such as in highly P-limited ecosystems, the relationship between maximal photosynthesis $\left(A_{\max }\right)$ and leaf $\mathrm{N}$ may be constrained by low P (Reich et al. 2009). Reich et al. (2010) reported the net photosynthesis rates to increase with increasing leaf $\mathrm{P}$ content, whereby $90 \%$ of their data points were below a leaf $\mathrm{P}$ concentration of $0.27 \%$ by weight. Maximal biomass and grain yield are also reported for soybean at leaf $\mathrm{P}$ concentration of $0.2-0.3 \%$ by weight (Singh 
et al. 2018). Photosynthesis reaches $A_{\max }$ at about $0.2-0.3 \% \mathrm{P}$ by weight, with no clear relation between leaf $\mathrm{P}$ and $A_{\max }$ at higher $\mathrm{P}$ levels where photosynthesis is likely no longer affected by $P$ (Shane et al. 2004). These concentrations approximate $0.12 \mathrm{~g} \mathrm{P} \mathrm{m}^{-2}$ leaf and indicate that for a crop with full ground cover of leaf area index (LAI) of 6 to intercept full radiation would require a total amount of about $7.5 \mathrm{~kg} \mathrm{ha}^{-1}$ metabolically active $\mathrm{P}$ for aboveground biomass (Withers et al. 2014). Higher amounts of $P$ may not contribute to higher growth. About $40-80 \%$ of the $\mathrm{P}$ in vegetative plant organs is translocated to grains in wheat and rice (Rose et al. 2010; Dimkpa et al. 2018a). In soybean Dimkpa et al. (2017a) observed a temporal decline in soybean vegetative (shoot and stem) $\mathrm{P}$ content from 261 to $203 \mathrm{mg}$ plant $^{-1}$, even as grain $\mathrm{P}$ content increased from 76 to $128 \mathrm{mg} \mathrm{plant}^{-1}$. This indicated that $\mathrm{P}$ was at least in part being remobilized from shoot to grain as the plant underwent reproductive development. Thus, as noted by several authors, $\mathrm{P}$ remobilized from vegetative organs to the grain could account for about $25-30 \%$ of the grain P (Tiryakioğlu et al. 2014; Tian et al. 2017; Xie et al. 2018). The remaining grain $P$ is taken up during the reproductive phase. Total crop P, therefore, would include about $3 \mathrm{~kg} P$ in the stubble and $12 \mathrm{~kg}$ in grains per hectare at a yield level of 4-8 $\mathrm{t} \mathrm{ha}^{-1}$.

Vandamme et al. (2016) observed that the linear relation between grain $\mathrm{P}$ content and grain yield of rice plateaued at around $0.25 \%$ grain P by weight. Rose et al. (2010) reported that variation in grain $P$ concentrations of 0.20 to $0.32 \%$ by weight does not correlate to grain yield or seed size. These findings suggest that leaf and grain P contents above a threshold level no longer have beneficial effects. Thus, total plant $\mathrm{P}$ uptake can be regulated by modulating supply to align with the plant $\mathrm{P}$ requirement.

Uptake of $\mathrm{P}$ from soil by plants under optimal growth ranges from 20 to $50 \mathrm{~kg} \mathrm{ha}^{-1}$ (Heming 2007; D'Haene and Hofman 2015). The difference with the amount needed to meet physiological requirements, implies that, in many instances, less $\mathrm{P}$ is required for optimal plant growth, relative to the amount of $\mathrm{P}$ supplied and taken up by the plant. Foyer and Spencer (1986) observed large differences in vacuolar P (non-metabolic pool) content among plants grown with different levels of phosphate supply, whereas cytoplasmic P (metabolic pool) is maintained at a constant level. Thus, much of the $\mathrm{P}$ is stored in vacuoles as phytate (the salt form of phytic acid; PA), buffering the $P$ in the cytoplasm (Shane et al. 2004). At critically low levels of cellular phosphate, vacuolar $\mathrm{P}$ is depleted, to maintain cytoplasmic inorganic $\mathrm{P}(\mathrm{Pi})$ homeostasis.

Schlemmer et al. (2009) provided data on phytate in various crops. Phytate accounts typically for $60-80 \%$ of total $\mathrm{P}$ in cereal grains, and 25-90\% of total P in other seeds and fruits. The phytate content in cereals and legumes ranges from 5 to $25 \mathrm{~g} \mathrm{~kg}^{-1}$ grain, equivalent to 1.5 to $7.7 \mathrm{~g} \mathrm{P} \mathrm{kg}^{-1}$ grain. Oilseeds may contain 25 to $60 \mathrm{~g}$ phytate $\mathrm{kg}^{-1}$ grain. Small amounts of phytate have been reported in roots, tubers, and vegetables. Alkarawi and Zotz (2014) further report that phytate makes up about 5-7\% of total $\mathrm{P}$, or approximately $2.3 \mathrm{mg} \mathrm{g}^{-1}$, on an average, with a median value of only $0.5 \mathrm{mg} \mathrm{g}^{-1}$, in a wide variety of crop leaves; phytate proportion hardly changes with total P. Dietary intake of phytate, therefore, will depend on diet composition. For adults, this ranges from 180 to $370 \mathrm{mg}$ day $^{-1}$ for Western-style diets to over $1100 \mathrm{mg}$ for vegetarians (Schlemmer et al. 2009). For Asian and African countries, higher intake levels of 500 to $4000 \mathrm{mg} \mathrm{day}^{-1}$ are found to be associated with higher intake of plant-based products (Ma et al. 2007; Joy et al. 2014).

Phytate has several beneficial properties, such as being an anticarcinogen, a strong antioxidant, and an inhibitor of kidney stone formation (Graf et al. 1987; Thompson and Zhang 1991; Schlemmer et al. 2009). On the contrary, phytate inhibits the bioavailability of zinc $(\mathrm{Zn})$, iron $(\mathrm{Fe})$, and $\mathrm{Ca}$ to humans, contributing to nutrient deficiencies. In developing countries, the combination of high phytate intake and inadequate intake or deficiencies of trace elements, particularly Fe and $\mathrm{Zn}$, will exacerbate malnutrition. The ratio of $\mathrm{PA} / \mathrm{Zn}$ and $\mathrm{PA} / \mathrm{Fe}$ is a first proxy for bioavailability of $\mathrm{P}, \mathrm{Zn}$, and $\mathrm{Fe}$. According to the WHO (1996), Zn absorption by humans reaches $50 \%$ at $\mathrm{PA} / \mathrm{Zn}$ molar ratio less than $5 ; 30-35 \%$ at ratio $5-15 ; 15 \%$ at ratio greater than 15 ; and less than $10 \%$ at ratio 25 or higher.

Notably, the concentrations of several micronutrients, including $\mathrm{Zn}$ and $\mathrm{Fe}$, in grains of cereal crops and in vegetables have declined, sometimes by more than half, over the past five decades (Mayer 1997; Davis et al. 2004; White and Broadley 2005; Garvin et al. 2006; Graham et al. 2007; Fan et al. 2008). This is a result of decades of breeding crops for higher yields (Bänziger and Long 2000; Monasterio and Graham 2000), increased use of NPK-only fertilization, and gradual increase in atmospheric $\mathrm{CO}_{2}$ concentration (Myers et al. 2014) that enhanced growth and yield. Depletion of soil micronutrients due to continuous cropping without adequate replenishment also has contributed to these declines (Jones et al. 2013; Shukla et al. 2015). Consequently, reducing the phytate content of edible plant parts becomes even more critical for enhancing their nutritional quality. While the ultimate impact on human nutrition and health may be distant, Bindraban et al. (2018) in their review paper expand on the potential impact of micronutrient fertilization on nutritional quality, exemplified by the proven impact of selenium on human nutrition. In analogy with multi-million-dollar investments in genetic biofortification with the promise of increasing micronutrient uptake by humans, that is yet to be proven (Saltzman et al. 2017), we postulate that it is worth exploring the nutritional dimension related to $\mathrm{P}$, even as a conceptual start to the process of aligning plant nutrition and human nutrition.

Overall, $\mathrm{P}$ fertilization tends to increase straw and grain yield, and, consequently, total P content. However, at the same 
time, it reduces $\mathrm{Zn}$ content, worsening $\mathrm{PA} / \mathrm{Zn}$ ratios (Zhang et al. 2017b). Fe concentration is less affected, but its bioavailability is reduced due to increased PA/Fe molar ratio (Fig. 1). Buerkert et al. (1998) noted that the increase in total $\mathrm{Zn}$ uptake at $13 \mathrm{~kg} \mathrm{ha}^{-1} \mathrm{P}$ fertilization in millet observed with a concomitant decrease in $\mathrm{Zn}$ concentration resulted from dilution, rather than from P-induced $\mathrm{Zn}$ deficiency. Thus, the antagonistic relationship between $\mathrm{P}$ and $\mathrm{Zn}$ and biomass growth improvement causing dilution effect could both be at play in affecting Zn concentrations. Ryan et al. (2008) reported similar findings, with $20 \mathrm{~kg} \mathrm{P} \mathrm{ha}^{-1}$ reducing wheat grain $\mathrm{Zn}$ concentration by $30-40 \%$. The authors ascribed their observations to a $50 \%$ decrease in root length colonization of arbuscular mycorrhizal fungi (AMF) that otherwise assist in uptake of less mobile nutrients, such as Zn. In a 16-year trial with maize, a decrease in the number of mycorrhizae spores and corn root mycorrhizal colonization were reported due to $\mathrm{P}$ treatments (Ortas and Islam 2018). Zhang et al. (2017a) also argued that $\mathrm{P}$ application may have decreased $\mathrm{Zn}$ uptake by roots. In general, grain $\mathrm{Zn}$ concentration decreases with increasing $\mathrm{P}$ fertilization. The suppressing impact of $\mathrm{P}$ fertilization on $\mathrm{Zn}$ and, to a lesser extent, on $\mathrm{Fe}$ and $\mathrm{Ca}$ concentrations, associated with the increase in phytate content, exacerbates the deteriorating nutritional quality of agricultural produce.

\section{Approaches to improve nutritional quality by reducing phytate content}

In plant-based diets, reducing phytate content, while simultaneously increasing $\mathrm{Zn}$ or Fe content, will improve nutrient bioavailability, thereby reducing malnutrition. Any strategy to reduce human phytate intake should consider the implications for total intake of P. Total P intake in European countries of over $1500 \mathrm{mg} \mathrm{day}^{-1}$ (Welch et al. 2009) substantially exceeds reference $\mathrm{P}$ nutrient intake of $550 \mathrm{mg}$ day $^{-1}$ (British Nutrition Foundation 2017). Similarly, the P intake levels in developing countries are likely to exceed reference intake as well, given the high consumption of predominantly plantbased diets. This could justify a reduction in the total amount of $\mathrm{P}$ in seeds through reducing the phytate content of grains meant for human consumption. However, such reduction is not applicable to seeds intended for use in plant propagation, given the high early $\mathrm{P}$ needs of young seedlings. Raboy (2009) outlined approaches and challenges to engineer low phytate and low total $\mathrm{P}$ seeds that could be an ideal seed $\mathrm{P}$ trait for human consumption. This author distinguished "cellular P", representing the sum of all P-containing compounds, such as $\mathrm{P}$ in DNA, RNA, proteins, lipids, and carbohydrates, but which excludes PA and Pi (Fig. 2). In the figure, available and non-available phosphate refers to nutritional availability for non-ruminants and assumes that available $\mathrm{P}$ approximately equals the sum of all $\mathrm{P}$ other than phytic acid P. Douglas et al. (2000) observed in monogastric animals that $P$ in low-phytate corn was two to three times more bioavailable than $\mathrm{P}$ in conventional corn and that the digestibility of amino acids in highprotein/low-phytate corn was equal to or higher than that in conventional corn.

Considerable variation in phytate-micronutrient content is reported for crop varieties. Other than agronomic practices, strategies such as screening for genetic variability, identification of low PA (lpa) mutants, developing transgenics, and use of molecular markers have been employed to reduce the seed PA content (Perera et al. 2018). In japonica rice, the genotypic variation in seed PA content ranged from 0.68 to $1.03 \%$ (Liu 2005) but it is yet to establish what proportion of this trait is genetically heritable. Mutation in genes responsible for
Fig. 1 Effect of $\mathrm{P}$ fertilization on grain nutrient and phytate (PA) concentration relative to zero $\mathrm{P}$ application. Values in bars are numbers of observations. Error bars $2 * \mathrm{SD}$ (sources: Buerkert et al. 1998; Ryan et al. 2008; Zhang et al. 2017a, b: Su et al. 2018)

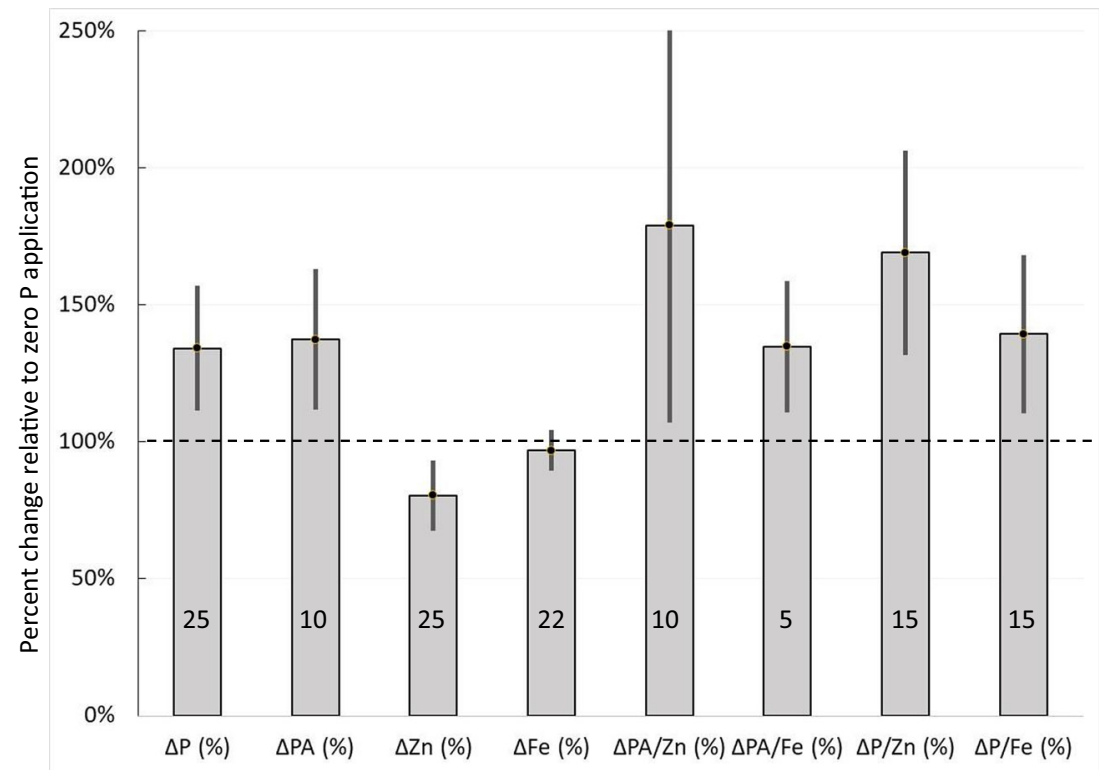




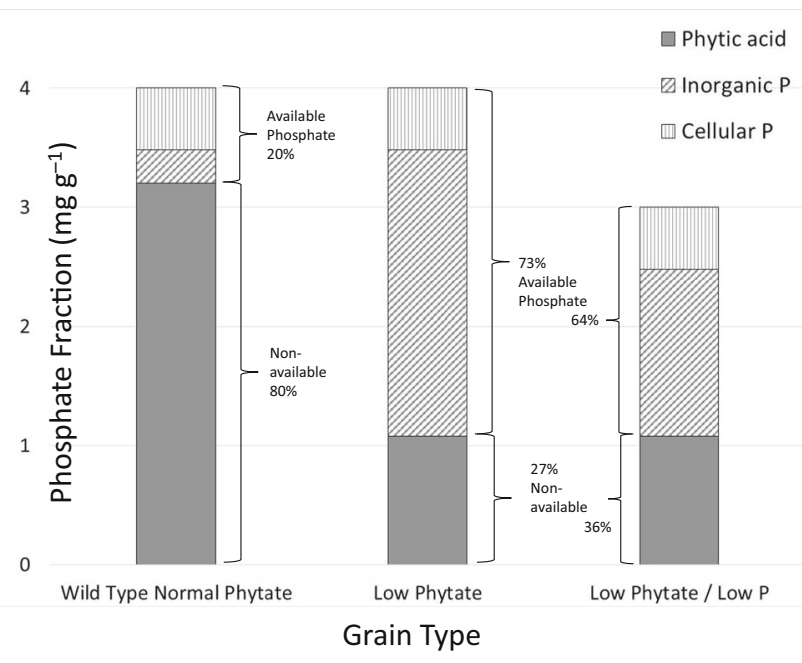

Fig. 2 Seed phosphate fractions in conventional or wild-type grains and legumes in comparison to low-phytate and low-phytate/low-P lines or cultivars (adapted from Raboy 2009)

synthesis of PA in seeds have been identified in several crops such as wheat, maize, barley, rice and soybean (Raboy 2000; Hitz et al. 2002; Dorsch et al. 2003; Pilu et al. 2003; Guttieri et al. 2004; Liu et al. 2007) which led to a reduction by 45 to 95\% in PA accumulation in mutants as compared with wildtype seeds. However, the seeds developed by breeding or mutation are inferior with reduced germination, poor seedling establishment, and ultimately reduced yield. To overcome this limitation, the use of DNA marker and transgenic approaches has been adopted. Two quantitative trait loci (QTLs) have been identified for PA content from the mapping population in rice indicating that grain PA concentration is genetically controlled (Stangoulis et al. 2006). These QTLs were present on the chromosomes 5 and 12 and were flanked by molecular markers (RM 305, RM 178, RM 247, RM 179) without overlapping with other QTLs for micronutrient accumulation such as $\mathrm{Fe}, \mathrm{Mn}$, and $\mathrm{Zn}$. So, using these DNA markers in markerassisted plant breeding would reduce the level of PA in seed without compromising micronutrient content and agronomic performance. Besides, there are several genes involved in the synthesis of inositol phosphates and PA accumulation in grains, out of which two genes, namely, Ins(3)P1 synthase (RINO1) and inositol-pentakisphosphate 2-kinase 1 (IPK1) were successfully used to develop rice transgenics (Kuwano et al. 2009; Ali et al. 2013). These genes were silenced in seeds using seed-specific promoters that resulted in $68 \%$ reduction in PA accumulation with no adverse effect on seed germination or plant growth. Similarly, low PA transgenic lines were developed in soybean by silencing genes inositol polyphosphate 6-/3-/5-kinase (IPK2) and myo-inositol-3phosphate synthase (MIPS) with significant reduction in seed $\mathrm{PA}$ and increase in $\mathrm{Fe}, \mathrm{Zn}$, and Ca content (Punjabi et al. 2018; Kumar et al. 2019). It may take another 6-8 years to develop crop varieties with low PA and increased micronutrients without compromising on plant growth and grain yield either through conventional breeding or transgenic approaches. However, this time frame could be reduced through the recent concept of generation advancement by "speed breeding" (Ghosh et al. 2018) wherein plants can be grown from seedto-seed up to six times in a year-based on crop species.

In general, crop fertilization solely with $\mathrm{P}$ has a limited impact on yield, except on strongly P-limited soils such as Oxisols, where plants remain vegetative and do not produce grains without P fertilization (e.g., Fageria and Oliveira 2014). Under sufficient $\mathrm{N}$ and $\mathrm{K}$ fertilization, $\mathrm{P}$ may modestly increase yield by $10-20 \%$ across crops and soils. Accordingly, such minimal effect could be justification for using half of the recommended P application rate (Valkama et al. 2009) under sufficient $\mathrm{N}$ and $\mathrm{K}$ conditions. $\mathrm{P}$ utilization efficiency is enhanced when applied together with other nutrients, in particular N and K (Duan et al. 2004) and also sulfur (S) and Zn (Weldegebriel et al. 2018). The case of $Z n$ may be surprising, given undesirable interactions between $\mathrm{Zn}$ and $\mathrm{P}$. However, Zn plays a role in P-mobilizing processes in the rhizosphere, which will be explored in more detail below. Increases in root length and mass due to $\mathrm{P}$ fertilization have resulted in higher accumulations of $\mathrm{K}, \mathrm{Ca}$, and copper $(\mathrm{Cu})$ in millet (Buerkert et al. 1998); of N, Ca, Mg, K, S, Cu, and manganese (Mn) in legume cover crops (Fageria et al. 2016); and Ca in rice (Ryan et al. 2008). Indeed, mostly synergistic, rather than antagonistic, effects have been reported with several cations (Rietra et al. 2017). Yet, there is a negative impact on grain $\mathrm{Zn}$ and, to a lesser extent, $\mathrm{Fe}$ concentration. This justifies the identification of approaches to enhance $\mathrm{Zn}$ and $\mathrm{Fe}$ concentrations under P fertilization.

The application of $\mathrm{Zn}$ can simultaneously increase crop yield and grain $\mathrm{Zn}$ content under limited soil $\mathrm{Zn}$ availability (Drissi et al. 2015; Dimkpa et al. 2017a, b, 2018b, 2019a, b). Grain $\mathrm{Zn}$ content can be more than doubled, even under sufficient $\mathrm{Zn}$ soil supply, through foliar $\mathrm{Zn}$ application, while grain $\mathrm{P}$ or phytate content is not, or only modestly, affected (Zhang et al. 2012; Khan et al. 2018; Xia et al. 2018). As such, foliar $\mathrm{Zn}$ fertilization can significantly reduce the $\mathrm{PA} / \mathrm{Zn}$ molar ratio and increase the bioavailability of both $\mathrm{Zn}$ and $P$. Wang et al. (2015) demonstrated a marked reduction in PA/Zn ratio from over 30 in the control treatment to below 15 with $\mathrm{Zn}$ fertilization. However, in their study, the lowest $\mathrm{Zn}$ application rate was $60 \mathrm{~kg} \mathrm{Zn} \mathrm{ha}^{-1}$ and the highest $350 \mathrm{Zn} \mathrm{ha}^{-1}$. These rates exceed $\mathrm{Zn}$ application rates under common practice by 10- to 30-fold. With Zn uptake of 250-400 $\mathrm{g} \mathrm{ha}^{-1}$, these practices are highly unsustainable, but worthy of note to inform on the need for good fertilization practices. It is noteworthy in this context that Doolette et al. (2018) found foliar Zn-EDTA to be taken up and transported as chelates, rather than as ions. Compared with $\mathrm{Zn}$-EDTA, $\mathrm{ZnSO}_{4}$ at such high levels used by Wang et al. (2015) may attain toxic levels of ionic $\mathrm{Zn}$ that need to be complexed by ligands in the leaf, such as phytate and 
citrate, for further transport. Hence, slow release rates of foliar $\mathrm{Zn}$ fertilizers may be advantageous to reduce toxicity.

\section{Toward innovative $\mathbf{P}$ fertilizer products and fertilization technologies}

Several practices have been identified to enhance P recovery and utilization along the food chain, some of which have been mentioned above (e.g., Reijnders 2014; Chowdhury et al. 2017). It is worth noting that the specific practice to be adopted for optimizing P use by plants would originate from a better understanding of strategies used by plants themselves for P utilization. These strategies have been outlined by Elanchezhian R et al. (2015) and references herein). For example, alteration in root system architecture and morphology in response to $\mathrm{P}$ stress is a common phenomenon, while physiological and biochemical responses include exudation of organic acids, protons, enzymes (acid phosphatase), kinetic parameters, and mycorrhizal association. At the molecular level, there is upregulation of $\mathrm{P}$ starvation-induced genes such as high-affinity Pi transporters, phosphatases, anion efflux transporters, while maintaining cellular Pi concentration through several "bypass" enzymes involved in primary metabolic processes.

In this paper, we have refrained from presenting a detailed overview of $\mathrm{P}$ recovery-enhancing practices. Instead, we have focused more on practices related to $\mathrm{P}$ fertilizer products and fertilization strategies that affect yield and nutritional quality. Increasing crop yield while addressing the nutritional challenge of phytate and micronutrients requires modification of $\mathrm{P}$ fertilizer products and fertilization strategies to simultaneously maintain, if not enhance, the uptake of other nutrients, in particular $\mathrm{Zn}$ and Fe. Figure 3 depicts various pathways for processing and administering P-based fertilizers to soils and directly to plants as foliar treatments. These pathways are introduced in the following paragraphs. We note that this paper does not elaborate on the economic viability of the proposed pathways. Production costs might be minimal for acidulating phosphate rock with water-soluble phosphates, while additional cost of producing "nano P" could be a barrier to practical utilization. In any case, we propose (see Dimkpa and Bindraban 2018) that a comprehensive cost-benefit analysis of different pathways versus conventional $\mathrm{P}$ fertilizers be conducted, to determine whether yield increase, nutritional improvements, use of lower $\mathrm{P}$ rates, and environmental stewardship outcomes (reduced leaching losses) attributed to counterbalancing any incurred costs during production and marketing, either directly in the fertilizer pricing, or indirectly through (subsidized) payments for societal (health) ecosystems services.

\section{P-fertilizer processes, products, and technologies}

Use of organic substances and soil microorganisms Root exudates containing organic substances are important for conditioning the rhizosphere to influence nutrient bioavailability and uptake by plants, and nowhere are they more critical for this function than in low nutrient soil conditions (Dakora and Phillips 2002). Vengavasi and Pandey (2016) identified soybean genotypes that release large amounts of carboxylates under low P stress, and the root exudates can efficiently mobilize bound soil $\mathrm{P}$. These authors subsequently demonstrated that when grown in soil under natural environment, soybean genotypes efficient in root exudation also exhibited an improved photo-biochemical machinery, leading to higher photosynthesis and carbon fixation (Vengavasi and Pandey 2018). However, adding chemically produced chelating agents or organic acids to soils increases the solubility of $\mathrm{P}$ under laboratory conditions, but the impact on $\mathrm{P}$ availability and crop productivity is low or absent under pot or field conditions (Smit et al. 2013 and references herein). Nevertheless, the use of citric acid to coat the surface of the synthetic version of the naturally occurring P source, nano hydroxyapatite, enhanced $\mathrm{P}$ availability, and improved root development, shoot growth, and cob yield in maize (Samavini et al. 2018). Notably, the process of synthesizing nano hydroxyapatite involves increasing the solution $\mathrm{pH}$, which could affect $\mathrm{P}$ solubility. Since surface properties determine the outcome of the interaction of nanoscale materials with their environment (Dimkpa 2018), modifying the surface of the nano hydroxyapatite with citric acid helped to retune the material for a specific objective, in this case higher dissolution.

A variety of soil microbes can solubilize nutrients such as $\mathrm{P}$, $\mathrm{Fe}$, and $\mathrm{Zn}$, but the fraction of the solubilized nutrient taken up by the plant is not clearly known, as it is affected by the amount solubilized, nutrient requirement of microorganism, root exudation of organic acids, soil nutrient status, sorption capacity, $\mathrm{pH}$, and several other factors (Adesemoye and Kloepper 2009; Khande et al. 2017). A meta-analysis involving soil-based, plant growth-promoting microbes finds promising yield improvements of 10-20\%, especially under dry and high soil $\mathrm{P}$ conditions (Schütz et al. 2018). However, besides the fact that individual studies evaluating the effects of microbial inoculum on plant productivity are often not repeated, authors also in most cases do not identify the ecological drivers that cause higher yields, such as changes in nutrient uptake, nor do they exhaustively discuss the functional mechanisms, such as root proliferation or exudation. In this regard, specific to $\mathrm{P}$ availability is the role of mycorrhiza that co-exist with plants. Mycorrhization influences P relations with plants using a variety of mechanisms: (i) it helps to extend the root volume, and by so doing decrease the diffusion distance of $\mathrm{P}$ ions to plant roots, while simultaneously increasing the surface area for $\mathrm{P}$ absorption; (ii) it facilitates the 


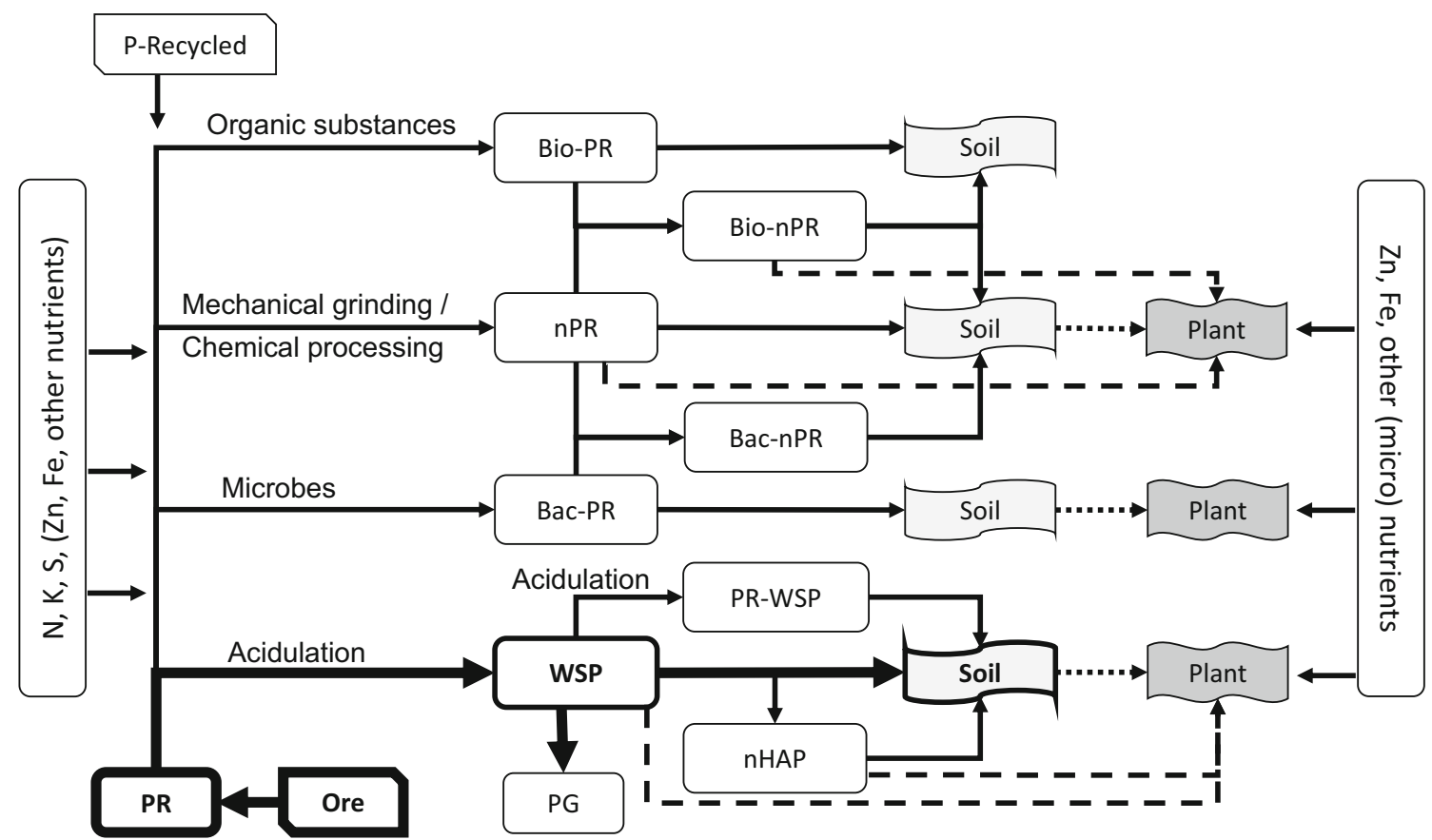

Fig. 3 Overview of pathways for P-based fertilizer production and modes of application (the conventional path of production and application are in bold letters and thick lines; continuous lines for processing and soil application; dotted lines indicate uptake from soils by plants; dashed lines indicate foliar application that bypasses the soil. $\mathrm{PR}=$ phosphate rock; $\mathrm{PG}=$ phosphogypsum; $\mathrm{WSP}=$ water-soluble $\mathrm{P} ; \mathrm{nHAP}=$ nano-hydroxyapatite; $\mathrm{PR}-\mathrm{WSP}=$ phosphate rock - water-aoluble $\mathrm{P}$ mixtures; $\mathrm{Bac}=$ microbial; $\mathrm{Bio}=$ organic substances; $\mathrm{nPR}=$ nano-size phosphate rock movement of $\mathrm{P}$ into the mycorrhizae-plant interface by increasing the affinity for $\mathrm{P}$ ions and by decreasing the threshold concentration for $\mathrm{P}$ absorption; and (iii) it promotes $\mathrm{P}$ solubilization by stimulating the excretion of organic acids, phosphatases, and other metabolites that increase the labile P pools from insoluble organic sources. Mycorrhizal plants have been shown to increase the uptake of $\mathrm{P}$ from poorly soluble $\mathrm{P}$ sources, such as $\mathrm{Fe}$ and $\mathrm{Al}$ phosphate and phosphate rock. Evidently, the exploitation of plant genotypic variability in terms of the degree of mycorrhizal fungi infection or root exudation of carboxylates and acid phosphatase enzymes shows promising results (Bolan 1991; Koele et al. 2014; Fan et al. 2018).

Phosphate-solubilizing bacteria (PSB) have been studied for their ability to solubilize $\mathrm{P}$ from phosphate rock, thereby improving plant growth and $\mathrm{P}$ uptake in various plant and soil systems (reviewed in Alori et al. 2017). Thus, the topic of PSB effects on crops is not intended to be covered in detail in this paper. However, in terms of $\mathrm{P}$ product development, Goldstein (2014) discusses how specific PSB and/or organic acids (e.g., gluconic acid) released by them to facilitate phosphate rock dissolution can be formulated with phosphate rock. Notably, the effectiveness of PSB solubilization of phosphate rock will vary with rock chemistry. Whereas high carbonate content phosphate rock is highly reactive, those with high fluoride content have less reactivity (Chien and Hammond 1978). Improvements in the formulation for higher efficiency can be achieved by increasing the phosphate rock surface area through preliminary grinding prior to formulation with PSB or organic acids, and by addition of a carbon source (glucose) as a feedstock for the biosynthesis of gluconic acids by the formulated PSB. Progress with respect to PSB/organic acidphosphate rock formulations has been reviewed by Vassileva et al. (2010) in which they discussed co-opting different agroindustrial wastes and phosphate rock as substrates in P solubilization by microorganisms under solid-state and submerged fermentation conditions. The authors also reviewed the multiple mechanisms by which P-solubilizing microorganism improve plant performance and soil properties, including production of enzymes, siderophores, and plant hormones. Notably, ex situ experimentation with these bio-products in the bioremediation of heavy metal contaminated and dry soils provided useful insights into the importance of these multifunctional properties. Hence, P-solubilizing microorganisms perform not one, but multiple roles that should be exploited for strategic application in biofertilization. In any case, such products must be evaluated for their shelf life, effectiveness under different temperature and humidity conditions, and ability to withstand the rough and tumble of transportation across national and international markets. In addition, the cost-benefit implications must be demonstrated through extensive field evaluations with different crops and soil types, in comparison with water-soluble $\mathrm{P}$ and unprocessed phosphate rock. 
Use of PSBs, combined with organic substances such as glucose, increases $\mathrm{P}$ availability from phosphate rock, primarily due to acidulation by organic acids produced by the microorganism. Apparently, the production of organic acids is enhanced in the presence of precursors such as glucose (Song et al. 2008). Conventionally, PSBs are selected based on their ability to dissolve tricalcium phosphate. However, as argued by Bashan et al. (2013a), tricalcium phosphate is relatively weak and unreliable for isolating and testing PSBs, relative to P-metal complexes. Hence, most PSBs identified in laboratory studies based on tricalcium phosphate dissolution have not lived up to the expectation of significantly contributing to $\mathrm{P}$ supply of plants. Based on these concerns, Bashan et al. (2013a, b) recommended that depending on soil $\mathrm{pH}$, rather than sole tricalcium phosphate, a combination of multiple metal-P compounds, with addition of phosphate rock, and with or without tricalcium phosphate, should be used together or in tandem as an initial selection factor.

Acidulation to improve $\mathbf{P}$ availability The goal of the conventional acidulation (or acidification) pathway through energy intensive and heavy chemical processing is to derive watersoluble P fertilizers from phosphate rock for soil application; phosphogypsum (PG) as a byproduct of this process. The effectiveness of water-soluble $\mathrm{P}$ is limited due to high tendency of fixation to soil particles. In contrast, direct application of phosphate rock as fertilizer is ineffective for uptake by plants due to low solubility. Accordingly, various innovative pathways can be pursued to "activate" phosphate rock sources that have demonstrated to be effective as $\mathrm{P}$ fertilizers under controlled conditions, but for which solid evidence for effectiveness under field conditions is yet to be established. Mixing of water-soluble $\mathrm{P}$ fertilizers with phosphate rock at different ratios enhances solubility due to acidulation. This strategy increases $\mathrm{P}$ uptake to levels comparable to those from sole water-soluble Ps, depending on the mixture ratios, and soil properties such as pH (IFDC 2018).

Various milling processes that reduce phosphate rock particle size to increase solubility can provide low-cost alternative approaches to the production of water-soluble $\mathrm{P}$ fertilizers. However, finely ground phosphate rock has been shown to insufficiently improve phosphate rock effectiveness (Ibrahim et al. 2010). To further improve efficacy, ultra-fine grinding of phosphate rock to $10-20 \mu \mathrm{m}$ and combining with lignin which activates the phosphate rock has been found to enhance $\mathrm{P}$ uptake to levels comparable to, if not better than, water-soluble $\mathrm{P}$ fertilizers in pot experiments (Huang et al. 2014). Combining equal amounts of water-soluble $P$ fertilizers, such as single superphosphate or triple superphosphate, with phosphate rock increases the uptake of $\mathrm{P}$ from the phosphate rock by $100 \%$ or more, when compared with sole phosphate rock application (Chien et al. 1996). This is due to the acidulating effect of water-soluble $\mathrm{P}$ on phosphate rock.
Formulations of water-soluble $\mathrm{P}+$ phosphate rock have been recommended as an agronomically and economically attractive option for utilizing indigenous phosphate rocks, based on field trials in Asia, sub-Saharan Africa, and Latin America (Chien and Menon 1995). Recently, the International Fertilizer Development Center (IFDC 2018; AgyinBirikorang, personal communications) has been optimizing the mixtures of different water-soluble P fertilizers with phosphate rocks from different geographical sources, in order to maximize $\mathrm{P}$ uptake by plants and increase economic benefits for the farmer. Preliminary greenhouse pot experiments revealed that diammonium phosphate, when combined with phosphate rock at a 1:4 ratio, markedly enhanced $\mathrm{P}$ uptake. Diammonium phosphate is a more commonly available watersoluble $\mathrm{P}$ fertilizer source than triple superphosphate in most developing countries and has a stronger acidulation effect. Crop yield obtained with the water-soluble P-phosphate rock combination at the $1: 4$ ratio is similar to that from diammonium phosphate in alkaline soils ( $\mathrm{pH} 7.8$ ), while it exceeds yield by nearly two-fold, compared with yield from diammonium phosphate in acidic soils ( $\mathrm{pH} 4.7$ ). We hypothesize that the prompt and high bioavailability of water-soluble P stimulated early root development and seedling growth that, in turn, enhanced the uptake of the "acidulated phosphate rock" subsequently. This temporal supply of P ensures its continuous provision during the entire plant growth cycle. Field trials in several countries in Africa are currently underway and promise to provide useful data to support scale-up and extensive recommendation of this product on the continent.

Nanotechnologies for improving $\mathbf{P}$ use Recent advances in nanotechnology suggest the possibility of decreasing $\mathrm{P}$ loss while increasing its plant use efficiency. Nanotechnology is the exploitation, production, modification, and utilization of materials at the nanoscale $(\leq 100 \mathrm{~nm})$. Nanoscale materials are more reactive than conventional materials, due to their greater surface area. Various physically or chemically produced nanoscale $\mathrm{P}$, such as nano-hydroxyapatite, can modulate $P$ release rates to more precisely meet crop demand and reduce losses from imprecise supply. Some of these advanced Pfertilizer products can be applied directly to foliage, thereby circumventing soil complex chemistry.

Nanotechnology has been applied to modulate P solubility, relative to highly water-soluble $\mathrm{P}$ forms [e.g., monoammonium phosphate, diammonium phosphate, and triple superphosphate (to reduce solubility)] and highly insoluble phosphate rock (to increase solubility). Accordingly, the synthesis of "nano-P" (nanoscale hydroxyapatite) has been reported (e.g., Liu and Lal 2014; Samavini et al. 2018). Nano-hydroxyapatite is produced in a stepwise reaction of calcium hydroxide or calcium chloride and phosphoric acid $\left(\mathrm{H}_{3} \mathrm{PO}_{4}\right)$. The stability of nano-P suspensions can be enhanced by addition of carboxymethyl 
cellulose or hexadecyl(cetyl) trimethyl ammonium bromide, which keeps the nanoparticles from aggregating. Soil treatment of soybean with nano-hydroxyapatite enhanced biomass $(17 \%)$ and grain yield (23\%), compared with triple superphosphate (Liu and Lal 2014). Similarly, application of nanohydroxyapatite in a sand matrix increased chickpea shoot between 49 and 96\%, relative to the control treatment (Bala et al. 2014). Unfortunately, this study did not compare the effect with water-soluble $\mathrm{P}$ or phosphate rock, nor was it conducted in actual soil. However, nano-hydroxyapatite increased $\mathrm{P}$ content of lettuce (13\%), with a corresponding shoot biomass increase (11\%), relative to $\mathrm{H}_{3} \mathrm{PO}_{4}$ (Taşkın et al. 2018). Foliar application of nano-hydroxyapatite on baobab (Adansonia digitata) seedlings increased leaf $\mathrm{P}$ content by 55 and $38 \%$, compared with monoammonium phosphate or diammonium phosphate, leading to a leaf chlorophyll increase of 88 and $19 \%$, and a dry biomass increase of 90 and $35 \%$, respectively (Soliman et al. 2016). Collectively, although nanohydroxyapatite was not always compared with water-soluble $\mathrm{P}$ and phosphate rock in these examples, positive effects were reported in all cases. This points to the strong potential of nanohydroxyapatite for increasing P uptake. Invariably, increasing $\mathrm{P}$ uptake efficiency would reduce the rate of $\mathrm{P}$ addition into the ecosystem, allowing for reducing both environmental $\mathrm{P}$ loss and overall P content of crops for less quantity of phytate.

Uptake of intact $P$ nanoparticles has been observed in plants exposed to nano-hydroxyapatite from the root (Bala et al. 2014). The relatively reduced solubility and mobility of nano-hydroxyapatite in soil (Liu and Lal 2014) ensure more residual soil $\mathrm{P}$ and subsequent plant uptake. Thus, using nanoscale $\mathrm{P}$ in agriculture will minimize $\mathrm{P}$ leaching or fixation. Furthermore, foliar application could portend a novel method of $\mathrm{P}$ delivery, given reported uptake efficiency of intact nanoparticles via leaves (Soliman et al. 2016). In any case, functionalizing nano-P allows for repurposing it for modulating P uptake, where levels in edible plant tissues need to be regulated to counteract undesirable interactions with other essential elements such as Zn. Kottegoda et al. (2017) demonstrated that formulating nano-hydroxyapatite with urea (1:6 ratio) can slow nutrient (N and $\mathrm{P}$ ) release. Rice yield was increased by $8 \%$ with the urea-nano hydroxyapatite, compared with conventional urea $+\mathrm{P}$ fertilization, while $\mathrm{P}$ uptake was similar between the two treatments. Thus, $\mathrm{P}$ in nano form could permit using less $\mathrm{P}$ to produce same yield, but with lower plant $\mathrm{P}$ content. Where enhancement of $\mathrm{P}$ uptake is required, nano-hydroxyapatite can be further improved by in situ addition of organic acids. Samavini et al. (2018) added citric acid during the synthesis stage of nano-hydroxyapatite, modifying the surface of the nano-hydroxyapatite and generating more discrete and stabilized particles, compared with pure nano-hydroxyapatite. $\mathrm{P}$ release from pure nanohydroxyapatite was $50 \%$ greater than from phosphate rock. However, addition of the organic acid during, rather than after, production generated a final citrate-hydroxyapatite nanocomposite with reduced $(74 \%)$ solubility, compared with the nanohydroxyapatite with ex situ-added organic acid, during the first 10 days. Nevertheless, the products showed similar P release rates after 50 days. Notably, in potted peat, the insitu citrate-nano-hydroxyapatite $\left(50 \mathrm{mg} \mathrm{P} \mathrm{kg}^{-1}\right)$ improved maize cob yield by $172-800 \%$ (dependent on the nano formulation), when compared with ex situ-derived citrate-nanohydroxyapatite; by $125-275 \%$, compared with triple superphosphate; and by $800-1400 \%$, compared with phosphate rock. Maize root biomass was also strongly improved by the in situ citrate-nano-hydroxyapatite products, compared with ex situ citrate-nano-hydroxyapatite, triple superphosphate, pure nano-hydroxyapatite, and phosphate rock, in that order.

Sharonova et al. (2015) described nano-P produced by physically grinding phosphate rock into nano-size particles and further processing by vanning (separation by repeated washing and swirling) in flowing water, concentrating (drying and activation in citric acid) and mixing in water. This generated a "nanostructured water-phosphorite suspension" containing up to $200 \mathrm{~g} \mathrm{P} \mathrm{L}^{-1}$. The nanostructured water-phosphate rock suspension was evaluated as a $\mathrm{P}$ source for plants at greenhouse and field scales. Specifically, in field studies in which the nanostructured water-phosphate rock suspension and phosphate rock (each at $0.4 \%$, in water) were foliarapplied to corn, fresh yield was increased $8 \%$ by nanostructured water-phosphate rock suspension, relative to conventional phosphate rock. In cucumber, seed-dressing with the nanostructured water-phosphate rock suspension produced yield increases of $15 \%$ using $0.25 \mathrm{~kg}$ of the nano suspension $\mathrm{t}^{-1}$ seed, and $20 \%$ using $1.25 \mathrm{~kg}$ of the suspension $\mathrm{t}^{-1}$ seed, when compared with $1.25 \mathrm{~kg} \mathrm{t}^{-1}$ of seed treated with conventional phosphate rock. Notably, foliar application of the nanosuspension at $0.25 \%$ in water also increased cucumber yield by $22 \%$, compared with a ground phosphate rock suspension at same concentration. Collectively, these results indicate strong potential of nano-P products, such as nanostructured water-phosphate rock suspension, in crop productivity as seed dressing and foliar amendments.

Recycling $\mathrm{P}$ to lower new $\mathrm{P}$ input The growing environmental challenges caused by $\mathrm{P}$ leaching losses, depletion of $\mathrm{P}$ reserves, and geopolitical inter-dependency on $\mathrm{P}$ have accelerated efforts to recover and recycle P. The main P-rich waste streams are manure, sewage sludge, slaughterhouse waste, and food waste. Utilization of these secondary phosphates as fertilizers is in its infancy. Extraction methods to recover P from waste and offal are being optimized to generate potential P fertilizers (Ueno and Fujii 2001; Rahman et al. 2014). Struvite (ammonium-magnesium phosphate) is a prominent example of recycled $\mathrm{P}$ from wastewater and sludge (Ohtake and Tsuneda 2019). Struvite is reported to perform as a slow release fertilizer (Talboys et al. 2016). Notably, the exportation 
of struvite from surplus regions in Europe to African countries with $\mathrm{P}$ scarcity is currently being explored (De Vries et al. 2017). Undoubtedly, existing $P$ extraction and recycling options hold a strong promise. Nevertheless, we argue that inculcating the knowledge of plant physiological processes driving nutrient use could result in more effective and appropriate fertilizers that meet plant $\mathrm{P}$ demand, rather than mere optimization of extraction methods that do not necessarily address the issue of meeting a precise plant $\mathrm{P}$ requirement. Moreover, composite nutrient products, specifically incorporating $\mathrm{Zn}$ and Fe in P-based fertilizers, are likely to be more effective for addressing the P-related food challenges, compared with sole $\mathrm{P}$ products, or products with inappropriate nutrient compositions. Nowhere in the world needs such products more than Africa, where, with only $5 \mathrm{~kg} \mathrm{ha}^{-1} \mathrm{P}$ being historically used (Ciceri and Allanore 2019), the challenges of nutrient shortfall and pervasive and acute hidden hunger must be met, head-on. However, such innovation and optimization should prevent the creation of environmental problems associated with excessive $\mathrm{P}$ use in Africa, as in other parts of the world. Approaches inappropriate to the specific conditions of the continent or that do not meet specific plant demand for P should, therefore, be discouraged.

To this end, advanced bio-nano technologies could contribute in improving the processes for extracting and deriving Pbased fertilizer products, and for coping with the complex edaphic processes and allowing novel modes and timing of $\mathrm{P}$ application to plants. In this regard, the concept of nanoparticles as potential sorption sites for $\mathrm{P}$ in soil has been noted as being behind the practical application of Fe-based nanoparticles for $\mathrm{P}$ recovery from wastewater streams (Kumar et al. 2018). By implication, sorption of $P$ from waste streams using Fe and utilization of the recovered product as fertilizer involves multiple nutrients, in this case Fe and P. Compared with struvite, this strategy potentially addresses the need for smart fertilization to simultaneously tackle the micronutrient deficiency challenges faced by resource-poor populations. The review of Kumar et al. (2018) discussed the role of sorption as a feasible process for the removal of $\mathrm{P}$ from aquatic environments serving as sinks for $\mathrm{P}$ due to excessive fertilization. The authors noted that $\mathrm{P}$ sorption can be achieved using sorbents such as conventional oxides of Fe, natural ores like calcite, and goethite. However, compared with these conventional sorbents, use of nanoscale Fe has gained attention due to its higher sorptive capacity for P. In one example of work in this area, a slurry of nanoscale Fe was used for P removal and recovery, whereby between 96 and $100 \%$ of $\mathrm{P}$, ranging in concentration between 1 and $10 \mathrm{mg} \mathrm{L}^{-1}$, was removed within $30 \mathrm{~min}$, with an efficacy that was 14 times higher than that of conventional Fe oxide (Almeelbi and Bezbaruah 2012). P recovered using this process increased spinach root and shoot growth by $243 \%$ and $255 \%$, respectively, compared with treatment with $\mathrm{Fe}$ (from ferric chloride) and $\mathrm{P}$ (from monopotassium phosphate) contained in the growth medium. These benefits occurred with an 11-fold increase in Fe uptake in the leaves of the nano-treated spinach plants, although leaf $\mathrm{P}$ uptake was not differentially affected by the P-sorbed nanoFe, compared with $\mathrm{P}$ from the growth medium (Almeelbi and Bezbaruah 2014). The similarity in $P$ content between the treatments indicated that $\mathrm{P}$ recovered from waste streams using nanotechnology could be as equally bioavailable to plants as $\mathrm{P}$ from a conventional nutrient source. Therefore, the successful rapid removal of $\mathrm{P}$ by nanoscale $\mathrm{Fe}$ from aqueous environments is expected to have widespread application in the clean-up of P-rich waters, with the recycling of the recovered $\mathrm{P}$ contributing to reduction of the input of new $\mathrm{P}$ into the agricultural space, and together with the Fe, provide more balanced nutrition for the plant.

Harnessing beneficial nutrient interactions to improve $P$ use efficiency in soil The optimization of nutrient combinations, in particular $\mathrm{N}$ and $\mathrm{P}$ for growth, and $\mathrm{Zn}$ and Fe for quality, is essential for developing nutrition-sensitive fertilizers that increase nutrient uptake efficiency. However, such optimization should be fine-tuned to specific crops and agro-ecologies to better address local and regional $\mathrm{P}$ peculiarities (Dimkpa and Bindraban 2016; Kihara et al. 2017; Njoroge et al. 2018). There is evidence that when bioavailable $\mathrm{P}$ is limited in soil, the application of micronutrients can contribute to native $\mathrm{P}$ mobilization, leading to improved $\mathrm{P}$ use efficiency in terms of plant growth and $\mathrm{P}$ uptake, even without additional $\mathrm{P}$ fertilization. For example, Raliya and Tarafdar (2013) reported that fertilization with conventional $\mathrm{Zn}$ (bulk $\mathrm{Zn}$ oxide) by foliar application $\left(25 \mathrm{~mL} /\right.$ plant of $\left.10 \mathrm{mg} \mathrm{Zn} \mathrm{L}^{-1}\right)$ increased shoot and root elongation of cluster bean by $7 \%$ and $16 \%$, respectively. This outcome was concomitant with a $53 \%$ increase in root area, which allowed $8 \%$ more shoot $\mathrm{P}$ accumulation, compared with the control plants. Notably, the alkaline soil used in the study contained a high amount of total $\mathrm{P}$ (733 $\mathrm{mg} \mathrm{kg}^{-1}$ ) of which, ostensibly, only a small fraction would be bioavailable; no additional $\mathrm{P}$ application was made. $\mathrm{Zn}$ is a co-factor for many enzymes (Nelson et al. 2008); thus, activation of P-mobilizing microbial enzymatic activities in the rhizosphere by $\mathrm{Zn}$ is very likely. In agreement with this role, Raliya et al. (2016) reported increased activities of specific P-solubilizing enzymes in mung bean rhizosphere, including acid and alkaline phosphomonoesterase, and phytases, by foliar application $(25 \mathrm{~mL} /$ plant of $10 \mathrm{mg}$ $\mathrm{Zn} \mathrm{L}{ }^{-1}$ ) of $\mathrm{Zn}$. Both nano [22.4 nm] and bulk scale $\mathrm{ZnO}$ were used in the study, to demonstrate nutrient particle size-specific effects. The increases with nano $\mathrm{ZnO}$ treatment were $44 \%$, $60 \%$, and $60 \%$, respectively, compared with the control (no $\mathrm{Zn}$ ) treatment, and $37 \%, 20 \%$, and $30 \%$, compared with bulk $\mathrm{ZnO}$ treatment. Interestingly, the increased microbial Penzyme activity induced by $\mathrm{Zn}$ was associated with $21 \%$ lower soluble $\mathrm{P}$ in the soil, compared with the control, suggesting 
that $\mathrm{P}$ was being mobilized from fixed pools in the soil. However, compared with the control, a modest $2 \%$ increase in $\mathrm{P}$ uptake in the plant was reported with bulk $\mathrm{ZnO}$, while nano $\mathrm{ZnO}$ increased $\mathrm{P}$ uptake by $9 \%$, relative to the bulk $\mathrm{ZnO}$. Overall, root development (length, area, and nodulation) was enhanced $27 \%$ by $\mathrm{Zn}$ treatment, relative to control plants. In addition to these effects, bulk $\mathrm{ZnO}$ caused higher abundances of soil bacteria, fungi, and actinomycetes than the control treatment. Interestingly, these microorganisms were $14 \%$, $17 \%$, and $17 \%$, respectively, more abundant with nano $\mathrm{ZnO}$ treatment, compared with bulk $\mathrm{ZnO}$ treatment. These nanospecific effects were likely due to a variety of reasons related to nanoscale materials. Firstly, nanoparticles can be transported basipetally (Wang et al. 2012). Secondly, nanoparticles can have higher reactivity in terms of dissolution rate, which drives rapid solubilization of bioactive $\mathrm{Zn}$ ions and internalization by the plant. Moreover, the significantly smaller size of the nano- $\mathrm{Zn}$ could facilitate uptake of the intact nanomaterial via the leaf stomata, as indicated with other nanomaterials (Wang et al. 2013; Larue et al. 2014). Once inside the leaf cells, the nanoparticles and/or dissolved ions can be translocated via the phloem to the root and then the soil (Wang et al. 2012; Elmer et al. 2018). Thus, the combined action of the intact nanoparticles and dissolved $\mathrm{Zn}$ ions caused greater availability of $\mathrm{Zn}$ passing through the plant to the soil microbes in the rhizosphere. This string of events enhanced the bioactivity of the $\mathrm{ZnO}$ nanoparticle treatment, relative to the bulk $\mathrm{ZnO}$ treatment. We note, however, that the study did not describe which plant tissue was analyzed for P; P could partition differently in tissues of different plants (Dimkpa et al. 2018b, 2019b). Remarkably though, these findings were reported in soil in which no additional $\mathrm{P}$ fertilization was applied, indicating that augmenting the plant with $\mathrm{Zn}$ can influence $\mathrm{P}$ dynamics and utilization in native soils with fixed $\mathrm{P}$ pools.

Although P-Zn interactions can have negative outcomes for the uptake of both nutrients due to the potential for formation of insoluble $\mathrm{Zn}$-phosphate complexes at high application rates, specific P-Zn fertilizer products can enhance plant uptake of P. For example, Watts-Williams et al. (2014) reported between 6 and $21 \%$ increases in tissue $P$ of tomato cultivars exposed to $\mathrm{Zn}$-phosphate-carbonate, compared with several other $\mathrm{Zn}$ products, including $\mathrm{Zn}$-sulfate, $\mathrm{Zn}$-oxide, $\mathrm{Zn}$-carbonate, and $\mathrm{Zn}$-phosphate. Concomitantly, $\mathrm{Zn}$ uptake was increased between 4 and $66 \%$ in the tissues of plants exposed to $\mathrm{Zn}$-phosphate-carbonate, compared with other treatments. In the study, the bioavailable soil P content was $12.8 \mathrm{~m} \mathrm{~kg}^{-1}$ ); $P$ levels were equalized in all treatments to a final rate of $25 \mathrm{mg} \mathrm{kg}^{-1}$. Thus, the effect of product type on $\mathrm{P}$ accumulation was not due to unbalanced $\mathrm{P}$ in the treatments. The $\mathrm{P}$ or $\mathrm{Zn}$ increases in the plant occurred even though Zn-phosphatecarbonate did not significantly enhance plant biomass, compared with other $\mathrm{Zn}$-fertilizer types. The findings for $\mathrm{Zn}$ - phosphate-carbonate is quite intriguing, as it would seem counterintuitive that the presence of carbonate, a major sink for soluble $\mathrm{P}$ in alkaline soil, would facilitate $\mathrm{P}$ uptake. However, we also noted that the given solubility of $\mathrm{Zn}$ phosphate-carbonate was low, relative to other product types; and also, that the particle size of the $\mathrm{Zn}$-phosphate-carbonate was $100 \mathrm{~nm}$ (Watts-Williams et al. 2014). This particle size range could facilitate the uptake of an intact $\mathrm{Zn}$-phosphatecarbonate compound by plants, thereby circumventing interactions with soil components that affect $P$ uptake. Interestingly, intact nano-scale $\mathrm{P}$ particles were observed in aboveground plant tissues upon treatment from root (Bala et al. 2014), supporting the possibility of uptake of nano-size $\mathrm{Zn}$-phosphate-carbonate. Thus, fertilizer products such as $\mathrm{Zn}$ phosphate-carbonate can simultaneously improve $\mathrm{P}$ and $\mathrm{Zn}$ use efficiency, despite the negative interaction between these nutrients. Obviously, more studies are needed with different crop species and soil types, as well as to understand the potential mechanisms of uptake of specific $P$ products by plants.

Exposure to $\mathrm{Fe}_{2} \mathrm{O}_{3}$ nanoparticles was thought to influence plant $\mathrm{P}$ accumulation from an alkaline soil by providing adsorption sites for $\mathrm{P}$ (Zahra et al. 2015). The $\mathrm{Fe}_{2} \mathrm{O}_{3}$ nanoparticles caused a dose-dependent $21-79 \%$ increase in dissolved $\mathrm{P}$ in soil, relative to the control treatment. Consequently, dissolved P in soils increased P uptake (25-100\% more P, relative to the control) in lettuce root, in turn, promoting root development (30-60\% in dry root biomass), enhancing shoot $\mathrm{P}$ accumulation (40-88\%), and ultimately, shoot development (6-26\% in dry root biomass), compared with the control soil. In a feedback mechanism, root growth stimulation resulted in higher root exudation of organic acids that contributed to lowering the rhizosphere $\mathrm{pH}$ (with $\mathrm{pH}$ dropping from $>7.9$ to 7.3). This further contributed to more $\mathrm{P}$ solubilization and uptake (Zahra et al. 2015). Unfortunately, the $\mathrm{Fe}_{2} \mathrm{O}_{3}$ nanoparticles were not compared with a bulk equivalent to establish the nano-specificity of the observed effects.

In a different study, Srivastava et al. (2014) synthesized nano-pyrite $\left(\mathrm{FeS}_{2}\right)$ by a stepwise procedure involving a buffered reaction of ferric chloride and sodium citrate, followed by addition of sodium polysulfide, heating, stirring, separation by centrifugation, and washing. When the effect of the nanoproduct was evaluated on spinach in a soil without NPK fertilization, significant increases in leaf number, leaf area, and fresh and dry weights of the plant were reported, compared with the untreated control. While this study did not demonstrate a nano-specific effect of the pyrite owing to the absence of a bulk pyrite treatment, it did demonstrate that an amendment of $\mathrm{FeS}_{2}$ could increase crop yield in the absence of added P. To more directly address the relationship with P fertilization, Das et al. (2018) conducted a subsequent study in rice using soil with a moderate $\left(17 \mathrm{~kg} \mathrm{ha}^{-1}\right)$ bioavailable P content. The study treatments comprised untreated soil (control), NPK (40 kg P ha ${ }^{-1}$ from diammonium phosphate), $\mathrm{FeS}_{2}$ 
(50 $\mu \mathrm{g} \mathrm{mL}^{-1}$ as a seed dressing), and $\mathrm{FeS}_{2}+\mathrm{NPK}$. Rice tiller number and grain yield were significantly increased by all fertilizer treatments, compared with the control. Interestingly, however, there were no significant differences in the tiller number and grain yield obtained by using NPK, nano-FeS ${ }_{2}$, and nano-FeS 2 + NPK. Mechanistically, as proposed by the authors, nano-pyrite induces seed peroxidase activity which, in turn, facilitates seed germination and early plant establishment. Furthermore, increased chlorophyll production was also observed as a mechanism for pyrite improvement of plant productivity. These findings demonstrated that seed dressing with nano-pyrite caused an "NPK-equivalent effect" on rice productivity. Hence, the authors concluded that using nano- pyrite could permit crops to be cultivated with little or no need for adding new NPK to the soil. While this conclusion is valid, considering the outcome of the nano product treatment without NPK addition, it is likely that the effect will be short-lived. At some point in time, NPK would have to be added to the soil during subsequent cropping events. It would be interesting to evaluate the temporal residual effect of the nano- $\mathrm{FeS}_{2}$ treatment on crop performance.

Overall, the addition of non-P fertilizers such as micronutrients can have both positive and negative outcomes for $\mathrm{P}$ content of the crop. Micronutrients, such as $\mathrm{Zn}$ and Fe, even when applied through foliage, may stimulate $P$ availability under low soil $\mathrm{P}$ content. Yet, on the one hand, lowered $\mathrm{P}$ uptake in high $\mathrm{P}$ soils due to micronutrients such as $\mathrm{Zn}$ will improve the $\mathrm{Zn} / \mathrm{P}$ ratio thereby reducing the potential to form $\mathrm{Zn}$ phytate. On the other hand, lowered $\mathrm{P}$ content of plants due to inhibition of $\mathrm{P}$ uptake under high $\mathrm{P}$ fertilization by these other nutrients increases $\mathrm{P}$ fixation or leaching loss, depending on soil type.

\section{Effect of P-fertilization strategies}

Timing and placement Early plant development, especially of the root system, is critical for effective nutrient uptake throughout the growth cycle. P starvation inhibits plant root

Table 1 Effects of foliar P spraying on yield and nutritional content of different crops as compared with soil applied P

\begin{tabular}{|c|c|c|c|}
\hline Crop & Effects on yield & Effects on nutritional content & Ref. \\
\hline Rapeseed-mustard & $\begin{array}{l}\text { Improved yield (shoot length, leaf number, } \\
\text { leaf area, LAI, fresh weight, dry weight, } \\
\text { pod number (up to } 100 \% \text { increase), } \\
\text { seed number, and } 1000 \text {-seed weight }\end{array}$ & $\begin{array}{l}\text { Increased oil yield and fatty acid } \\
\text { composition in oil }\end{array}$ & Siddiqui et al. (2008) \\
\hline Spanish Peanut & Increased yield & $\begin{array}{l}\text { Total kernel P content, percentage } \\
\text { sound mature kernel }\end{array}$ & Sistani and Morrill (1992) \\
\hline Soybean & $\begin{array}{l}\text { Increased yield, higher number of pods } \\
\text { and number of seed pods per seed } \\
\text { index, and higher grain yield }\end{array}$ & & Kumar et al. (2013) \\
\hline Cowpea & & $\begin{array}{l}\text { Higher contents of protein, } \mathrm{N}, \mathrm{P} \text {, } \\
\text { and } \mathrm{K}\end{array}$ & Yadav and Choudhary (2012) \\
\hline Maize & $\begin{array}{l}\text { Increased plant height, flag leaf length, } \\
\text { grain, and biomass yield }\end{array}$ & & Yosefi et al. (2011) \\
\hline Wheat & Increased grain P uptake & & Benbella and Paulsen (1998) \\
\hline Apple & & Fruit color, post-harvest firmness & Wojcik and Wojcik (2007) \\
\hline Cotton & $\begin{array}{l}\text { Increased cotton seed yield, seed index, } \\
\text { and protein yields }\end{array}$ & $\begin{array}{l}\text { Increased seed oil on saponifiable } \\
\text { matter and total unsaturated fatty } \\
\text { acids (oleic, linoleic); decrease } \\
\text { oil acid value }\end{array}$ & Sawan et al. (2007) \\
\hline Common Bean & $\begin{array}{l}\text { No yield improvement under high soil } \\
\text { P availability }\end{array}$ & $\begin{array}{l}\text { Increased } \mathrm{P} \text { contents in grains even } \\
\text { in soils with high } \mathrm{P}\end{array}$ & Gonçalves et al. (2017) \\
\hline Maize & $\begin{array}{l}\text { Yield response to foliar } \mathrm{P} \text { and other } \\
\text { nutrients; increase also ascribed to } \\
\mathrm{P} \text {, complementing low soil } \mathrm{P} \text { availability. }\end{array}$ & & Jemo et al. (2015) \\
\hline Wheat & $\begin{array}{l}\text { Yield increase of } 25 \% \text { in one of the two } \\
\text { research soils }\end{array}$ & & McBeath et al. (2011) \\
\hline Common Bean & $\begin{array}{l}\text { Improved photosynthesis, water use } \\
\text { efficiency, and seed dry weight }\end{array}$ & & Dos Santos et al. (2004) \\
\hline Winter wheat & $\begin{array}{l}\text { Nutri-Phite, a phosphite-based product } \\
(3 \% \mathrm{~N}, 8.7 \% \mathrm{P} \text {, and } 5.8 \% \mathrm{~K}) \text { improved } \\
\text { grain yield }\end{array}$ & $\begin{array}{l}\text { Increased grain } \mathrm{P} \text { concentration } \\
\text { by } 11.6 \%\end{array}$ & Ali et al. (2014) \\
\hline Winter wheat & $\begin{array}{l}\text { Enhanced P use efficiency and grain } \\
\text { yield with foliar P applied }\end{array}$ & & Mosali et al. (2006) \\
\hline Corn and soybean & $\begin{array}{l}\text { Tri- and tetra-polyphosphate increased } \\
\text { grain yield in both crops }\end{array}$ & & Barel and Black (1979b) \\
\hline
\end{tabular}


elongation while inducing the proliferation of lateral roots (Péret et al. 2014). However, supposedly nutrient-poor soils may contain total (fixed) amounts of P that are 100 to 1000 times greater than crop demand (Van der Eijk et al. 2006). Thus, a well-developed root system is particularly relevant for the ability of extended roots to better scavenge larger soil volumes for P. Early soil P fertilization, especially when placed near the seed, helps to overcome the low soil $\mathrm{P}$ availability (de Willigen and van Noordwijk 1987) and allows the placement of only a fraction of the $P$ needed to achieve similar crop performance, compared with surface broadcasting. Chien et al. (2009) reported that maize yields increased from $7 \mathrm{t} \mathrm{ha}^{-1}$, with broadcast application of $11.6 \mathrm{~kg} \mathrm{P} \mathrm{ha}^{-1}$, to $8.5 \mathrm{tha}^{-1}$ with banding at the same rate. Microdosing of $3 \mathrm{~kg} \mathrm{P} \mathrm{ha}^{-1}$ in the planting hole or beneath the dry-seeded drilled rice was found to consistently increase early vigor and almost tripled grain yield to $3 \mathrm{tha}^{-1}$, with a $\mathrm{P}$ fertilizer agronomic efficiency of $356-817 \mathrm{~kg}$ grains kg ${ }^{-1} \mathrm{P}$, and a cost/benefit ratio of 3-12 in on-farm experiments, compared with broadcast of $6 \mathrm{~kg} \mathrm{P} \mathrm{ha}^{-1}$ (Vandamme et al. 2018). Coating of seeds with $\mathrm{P}$ has been found in several instances to stimulate growth and yield but may hamper germination at higher concentrations (Smit et al. 2013). Seed coating provides promising features for practical application, although it has yet to be investigated in great detail to maximize its benefits. Therefore, P-fertilization strategies that stimulate root growth at early stages of plant development, such as seed coating and P placement near seeds, may be very effective for enhancing $P$ use efficiency.

Foliar P application In addition to application via soil, $\mathrm{P}$ could be applied to plant foliage, where it is equally physiologically relevant. However, most of the studies on foliar P application are focused on descriptions of application methods and resultant uptake or yield responses, with only minimal fundamental reflections on the physiological mechanisms involved in its uptake through leaves (Fernández et al. 2013). Thus, a clearer understanding of such mechanisms may facilitate identification of effective compounds and chemical packaging methods to enhance leaf penetration (Fernández and Brown 2013). Foliar fertilizers are generally applied as a curative measure to overcome immediate deficiencies. However, foliar application is recognized as a viable strategy to improve qualitative traits of food produce, such as enhanced micronutrient content, in particular $\mathrm{Zn}$ and $\mathrm{Fe}$, or to increase produce shelf life, such as with boron (B) and Ca (Voogt et al. 2013; Rani et al. 2017; Sharma et al. 2019). Not surprisingly, foliar P fertilization has been reported to be effective under P-deficient soil conditions, as opposed to conditions of sufficient $\mathrm{P}$ supply (Noack et al. 2010) as compared with soil applied P. Foliar P application has been evaluated in various agricultural crops, including soybean, wheat, clover, and corn, and reported to increase photosynthetic efficiency, delay leaf senescence, and

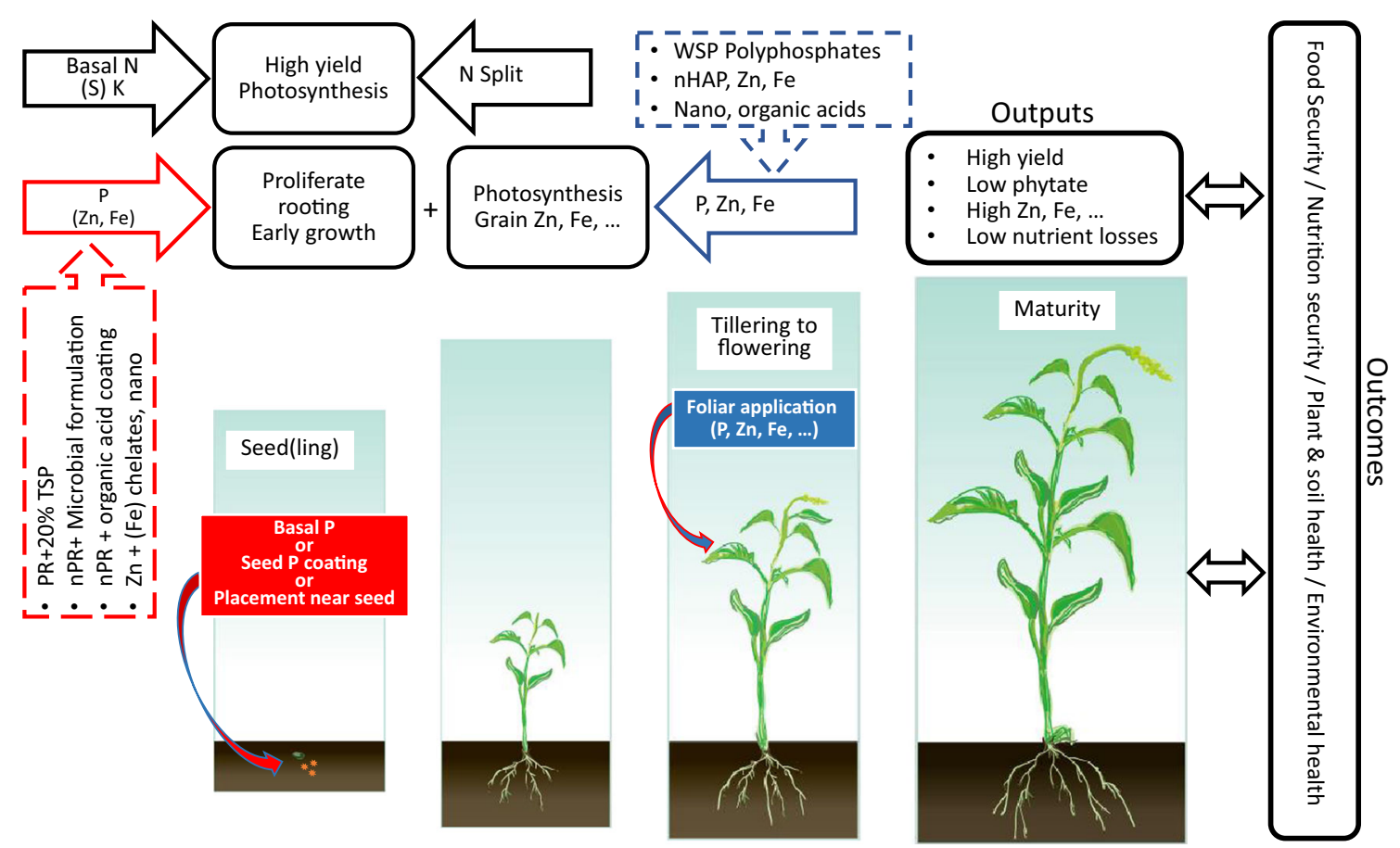

Fig. 4 Schematic presentation of timing (expressed as crop development stages) and mode of application (red and blue boxes for soil and foliar) of specific nutrients and their functionalities, along with physicochemical properties of P-based fertilizer products (left dashed box for soil applied $\mathrm{P}$, upper right dashed box for foliar P formulations). This schema exemplifies ways to attain anticipated outputs and social-environmental outcomes, while the outcomes, vice versa, govern fertilizer design and fertilization strategies. $\mathrm{PR}=$ phosphate rock; $\mathrm{nPR}=$ nano-size phosphate rock; WSP = water-soluble phosphate; $\mathrm{nHAP}=$ nano-hydroxyapatite; basal application = pre sowing fertilization; split application $=$ applying the total recommended fertilizer rates at different times, as opposed to one-time application 
increase yields as compared with soil applied P (Table 1). Upon foliar application, 30-60\% of the P may be taken up and translocated to other parts of the plant within 2 to 3 days. Subsequently, remobilization of $\mathrm{P}$ at high rates from older to younger leaves occurs, ostensibly contributing to delaying senescence. Foliar P application was reported to increase enzymatic activities related to sucrose production, leading to increased sugar content in sugarcane (Pawar et al. 2003). The most appropriate timing for foliar $\mathrm{P}$ application to increase growth rate and yield, ranges from canopy closure to anthesis or tasseling (Noack et al. 2010). Overdosing can cause leaf burn, but the detrimental effect depends on the phosphate formulation used, e.g., more $\mathrm{P}$ can be added in polyphosphate compounds, compared with orthophosphate forms. Maximum concentrations of $1.3 \%$ in solutions of triand polyphosphates have been noted, as compared with $0.5 \%$ orthophosphate on corn leaves without damaging the plant (Barel and Black 1979a). Application of ammonium tripolyphosphate, followed by ammonium polyphosphate and phosphoryl triamide, was evaluated on maize, and these were determined to be the most effective compounds, compared with orthophosphates in preventing damage (Noack et al. 2010).

\section{Reflections on P fertilization strategies for human and environmental health}

The need for P fertilization to guarantee food and nutritional security for the current 7.7, and future 10, billion global population is evident. $\mathrm{P}$ fertilization increases yield, but it also reduces the bioavailability of $\mathrm{Zn}, \mathrm{Fe}$, and other essential nutrients to humans and pollutes the environment, due to low plant uptake efficiencies. Innovative $P$ fertilizer products and fertilization strategies must, and can, be developed to markedly reduce these unintended negative environmental and health effects of excessive $\mathrm{P}$. The fact that the physiological $\mathrm{P}$ requirement is generally lower than the amount of $\mathrm{P}$ taken up by plants provides an opportunity to design and apply fertilization strategies to reduce total $\mathrm{P}$ supply and uptake, without penalty on the yield and nutritional value of the produce. Hence, improvement of the nutritional value of staple crops through reduced PA and increased $\mathrm{Zn}$ and $\mathrm{Fe}$ contents ought to be among the most important drivers for innovative fertilizer products and application technologies. This will contribute to fighting hunger and human deficiencies of essential micronutrients, reduce the total P supply and uptake by plants, enhance $\mathrm{P}$ uptake efficiency, and reduce residual $\mathrm{P}$ and runoff loss from fertilization. The end goal of these outcomes is the ultimate reduction in the amount of new $\mathrm{P}$ added into the agricultural space. The identified P-based fertilizer products and fertilization strategies elaborated in the previous sections have been systematically organized to exemplify possible crop management interventions in Fig. 4.
Bringing the promise of these technological opportunities to fruition calls for a transformation of the fertilizer sector, driven by a novel interest for fertilizers to simultaneously serve multiple societal goals. To this end, multiple stakeholders from various sectors, including nutrition and health, agriculture, environment, and fertilizer industry, must drive such transformation.

Acknowledgments This study was funded by United States Agency for International Development (USAID)'s Feed the Future Soil Fertility Technology Adoption, Policy Reform and Knowledge Management Project (Cooperative Agreement Number AID-BFS-IO-15-00001) to PSB and CD and by Virtual Fertilizer Research Centre (VFRC), Washington D.C., U.S.A. (Grant no. 02838/14) to RP.

Open Access This article is licensed under a Creative Commons Attribution 4.0 International License, which permits use, sharing, adaptation, distribution and reproduction in any medium or format, as long as you give appropriate credit to the original author(s) and the source, provide a link to the Creative Commons licence, and indicate if changes were made. The images or other third party material in this article are included in the article's Creative Commons licence, unless indicated otherwise in a credit line to the material. If material is not included in the article's Creative Commons licence and your intended use is not permitted by statutory regulation or exceeds the permitted use, you will need to obtain permission directly from the copyright holder. To view a copy of this licence, visit http://creativecommons.org/licenses/by/4.0/.

\section{References}

Adesemoye AO, Kloepper JW (2009) Plant-microbe interactions in enhanced fertilizer-use efficiency. Appl Microbiol Biotechnol 85:1-12

Ali N, Paul S, Gayen D, Sarkar SN, Datta K, Datta SK (2013) Development of low phytate rice by RNAi mediated seed-specific silencing of inositol 1,3,4,5,6-pentakisphosphate 2-kinase gene (IPK1). PLoS One 8:e68161

Ali MS, Sutradhar A, Edano ML, Edwards JT, Girma K (2014) Response of winter wheat grain yield and phosphorus uptake to foliar phosphite fertilization. Int J Agron \#801626

Alkarawi H, Zotz G (2014) Phytic acid in green leaves. Plant Biol 16: 697-701

Almeelbi T, Bezbaruah A (2012) Aqueous phosphate removal using nanoscale zero-valent iron. J Nanopart Res 14:7

Almeelbi T, Bezbaruah A (2014) Nanoparticle-sorbed phosphate: iron and phosphate bioavailability studies with Spinacia oleracea and Selenastrum capricornutum. ACS Sustain Chem Eng 2:1625-1632

Alori ET, Glick BR, Babalola OO (2017) Microbial phosphorus solubilization and its potential for use in sustainable agriculture. Front Microbiol 8:971

Ardö J, Tagesson T, Jamali S, Khatir A (2018) MODIS EVI-based net primary production in the Sahel 2000-2014. Int J Appl Earth Obs Geoinf 65:35-45

Bala N, Dey A, Das S, Basu R, Nandy P (2014) Effect of hydroxyapatite nanorod on chickpea (Cicer arietinum) plant growth and its possible use as nano-fertilizer. Iranian J Plant Physiol 4:1061-1069

Bänziger M, Long J (2000) The potential for increasing the iron and zinc density of maize through plant-breeding. Food Nutr Bull 21:397400

Barel D, Black CA (1979a) Effect of neutralization and addition of urea, sucrose, and various glycols on phosphorus absorption and leaf damage from foliar-applied phosphate. Plant Soil 52:515-525 
Barel D, Black CA (1979b) Foliar application of P. II. Yield response of corn and soybeans sprayed with various condensed phosphates and $\mathrm{P}-\mathrm{N}$ compounds in greenhouse and field experiments. Agron $\mathrm{J} 71$ : 21-24

Bashan Y, Kamnev AA, de-Bashan LE (2013a) Tricalcium phosphate is inappropriate as a universal selection factor for isolating and testing phosphate-solubilizing bacteria that enhance plant growth: a proposal for an alternative procedure. Biol Fertil Soils 49:465-479

Bashan Y, Kamnev AA, de-Bashan LE (2013b) A proposal for isolating and testing phosphate-solubilizing bacteria that enhance plant growth. Biol Fertil Soils 49:1-2

Benbella M, Paulsen GM (1998) Efficacy of treatments for delaying senescence of wheat leaves: I. senescence under controlled conditions. Agron J 90:329-332

Bindraban PS, Dimkpa C, Nagarajan L, Roy A, Rabbinge R (2015) Revisiting fertilisers and fertilisation strategies for improved nutrient uptake by plants. Biol Fertil Soils 51:897-911

Bindraban PS, Dimkpa C, Angle S, Rabbinge R (2018) Unlocking the multiple public good services from balanced fertilizers. Food Secur 10:273-285

Bolan NS (1991) A critical review on the role of mycorrhizal fungi in the uptake of phosphorus by plants. Plant Soil 134:189-207

Bouwman AF, Beusen AHW, Lassaletta L, van Apeldoorn DF, van Grinsven HJM, Zhang J, van Ittersum MK (2017) Lessons from temporal and spatial patterns in global use of $\mathrm{N}$ and $\mathrm{P}$ fertilizer on cropland. Sci Rep 7:40366

Breman H, Groot JJR, van Keulen H (2001) Resource limitations in Sahelian agriculture. Glob Environ Chang 11:59-68

British Nutrition Foundation (2017) "Nutrition Requirements. "https:// www.nutrition.org.uk/attachments/article/261/Nutrition\% 20Requirements Revised\%20Oct\%202017.pdf

Buerkert A, Haake C, Ruckwied M (1998) Phosphorus application affects the nutritional quality of millet grain in the Sahel. Field Crop Res 57: 223-235

Chien SH, Hammond LL (1978) A comparison of laboratory methods for predicting the agronomic potential of phosphate rocks for direct application. Soil Sci Soc Am J 42:935-939

Chien SH, Menon RG (1995) Agronomic evaluation of modified phosphate rock products. Nutr Cycl Agroecosyst 41:197-209

Chien SH, Menon RG, Billingham KS (1996) Phosphorus availability from phosphate rock as enhanced by water-soluble phosphorus. Soil Sci Soc Am J 60:4

Chien SH, Prochnow LI, Cantarella H (2009) Recent developments of fertilizer production and use to improve nutrient efficiency and minimize environmental impacts. Adv Agron 102:267-322

Chowdhury RB, Moore GA, Weatherley AJ, Arora M (2017) Key sustainability challenges for the global phosphorus resource, their implications for global food security, and options for mitigation. J Clean Prod 140:945-963

Ciceri D, Allanore A (2019) Local fertilizers to achieve food selfsufficiency in Africa. Sci Total Environ 648:669-680

Cleveland CC, Townsend AR, Taylor P, Alvarez-Clare S, Bustamante MM, Chuyong G, Dobrowski SZ, Grierson P, Harms KE, Houlton BZ, Marklein A, Parton W, Porder S, Reed SC, Sierra CA, Silver WL, Tanner EV, Wieder WR (2011) Relationships among net primary productivity, nutrients and climate in tropical rain forest: a pantropical analysis. Ecol Lett 14:939-947

Conijn JG, Bindraban PS, Schröder JJ, Jongschaap R (2018) Can our food system meet food demand within planetary boundaries? Agric Ecosyst Environ 251:244-256

Cordell D, Drangert J, White S (2009) The story of phosphorus: global food security and food for thought. Glob Environ Chang 19:292305

D'Haene K, Hofman G (2015) Phosphorus offtake and optimal phosphorus fertilisation rate of some fodder crops and potatoes in temperate regions. Agrokém Talajt 64:403-420
Dakora FD, Phillips DA (2002) Root exudates as mediators of mineral acquisition in low-nutrient environments. Plant Soil 245:35-47

Das CK, Jangir H, Kumar J, Verma S, Mahapatra SS, Philip D, Srivastava G, Das M (2018) Nano-pyrite seed dressing: a sustainable design for NPK equivalent rice production. Nanotechnol Environ Eng 3:14

Davis DR, Epp MD, Riordan HD (2004) Changes in USDA food composition data for 43 garden crops. J Am Coll Nutr 23:669-682

De Vries S, Postma R, Van Scholl L, Blom-Zandstra G, Verhagen J, Harms I (2017) Economic feasibility and climate benefits of using struvite from the Netherlands as a phosphate $(\mathrm{P})$ fertilizer in West Africa. Wageningen Research, Report WPR-673

De Willigen PD, Van Noordwijk M (1987) Roots, plant production and nutrient efficiency. PhD thesis, LU, Wageningen

Dimkpa CO (2018) Soil properties influence the response of terrestrial plants to metallic nanoparticles exposure. Curr Opin Environ Sci Health 6:1-8

Dimkpa C, Bindraban PS (2016) Micronutrients fortification for efficient agronomic production: a review. Agron Sustain Dev 36:1-26

Dimkpa C, Bindraban P (2018) Nano fertilizers: new products for the industry? J Agric Food Chem 66:6462-6473

Dimkpa C, Bindraban P, Fugice J, Agyin-Birikorang S, Singh U, Hellums D (2017a) Composite micronutrient nanoparticles and salts decrease drought stress in soybean. Agron Sust Dev 37:5

Dimkpa CO, White JC, Elmer WH, Gardea-Torresdey J (2017b) Nanoparticle and ionic Zn promote nutrient loading of sorghum grain under low NPK fertilization. J Agric Food Chem 65:85528559

Dimkpa CO, Singh U, Adisa IO, Bindraban PS, Elmer WH, GardeaTorresdey JL, White JC (2018a) Effects of manganese nanoparticle exposure on nutrient acquisition in wheat (Triticum aestivum L.). Agron 8:158

Dimkpa CO, Singh U, Bindraban PS, Elmer WH, Gardea-Torresdey JL, White JC (2018b) Exposure to weathered and fresh nanoparticle and ionic $\mathrm{Zn}$ in soil promotes grain yield and modulates nutrient acquisition in wheat (Triticum aestivum L.). J Agric Food Chem 66:96459656

Dimkpa CO, Singh U, Bindraban PS, Adisa IO, Elmer WH, GardeaTorresdey JL, White JC (2019a) Addition-omission of zinc, copper, and boron nano and bulk particles demonstrate element and sizespecific response of soybean to micronutrients exposure. Sci Total Environ 665:606-616

Dimkpa CO, Singh U, Bindraban PS, Elmer WH, Gardea-Torresdey JL, White JC (2019b) Zinc oxide nanoparticles alleviate droughtinduced alterations in sorghum performance, nutrient acquisition, and grain fortification. Sci Total Environ 688:926-934

Doolette CL, Read TL, Li C, Scheckel KG, Donner E, Kopittke PM, Schjoerring JK, Lombi E (2018) Foliar application of zinc sulphate and zinc EDTA to wheat leaves: differences in mobility, distribution, and speciation. J Exp Bot 69:4469-4481

Dorsch JA, Cook A, Young KA, Anderson JM, Bauman AT, Volkmann CJ, Murthy PPN, Raboy V (2003) Seed phosphorus and inositol phosphate phenotype of barley low phytic acid genotypes. Phytochem 62:691-706

Dos Santos MG, Ribeiro RV, de Oliveira RF, Pimentel C (2004) Gas exchange and yield response to foliar phosphorus application in Phaseolus vulgaris L. under drought. Braz J Plant Physiol 16:171179

Douglas MW, Peter CM, Boling SD, Parsons CM, Baker DH (2000) Nutritional evaluation of low phytate and high protein corns. Poult Sci 79:1586-1591

Drissi S, AïtHoussa A, Bamouh A, Coquant JM, Benbella M (2015) Effect of zinc-phosphorus interaction on corn silage grown on sandy soil. Agriculture 5:1047-1059

Duan Z, Xiao H, Dong Z, Li X, Wang G (2004) Combined effect of nitrogen-phosphorus-potassium fertilizers and water on spring 
wheat yield in an arid desert region. Commun Soil Sci Plant Anal 35:161-175

Elanchezhian R, Krishnapriya V, Pandey R, Rao AS, Abrol YP (2015) Physiological and molecular approaches for improving phosphorus uptake efficiency of crops. Curr Sci 108:1271-1279

Elmer W, De La Torre-Roche R, Pagano L, Majumdar S, Zuverza-Mena N, Dimkpa C, Gardea-Torresdey J, White JC (2018) Effect of metalloid and metallic oxide nanoparticles on Fusarium wilt of watermelon. Plant Dis 102:1394-1401

Fageria NK, Oliveira JP (2014) Nitrogen, phosphorus and potassium interactions in upland rice. J Plant Nutr 37:1586-1600

Fageria NK, Gheyi HR, Carvalho MCS, Moreira A (2016) Root growth, nutrient uptake and use efficiency by roots of tropical legume cover crops as influenced by phosphorus fertilization. J Plant Nutr 39:781792

Fan MS, Zhao FJ, Fairweather-Tait SJ (2008) Evidence of decreasing mineral density in wheat grain over the last 160 years. J Trace Elem Med Biol 22:315-324

Fan Y, Lin F, Yang LM, Zhong XJ et al (2018) Decreased soil organic P fraction associated with ectomycorrhizal fungal activity to meet increased $\mathrm{P}$ demand under $\mathrm{N}$ application in a subtropical forest ecosystem. Biol Fertil Soils 54:149-161

Fernández V, Brown PH (2013) From plant surface to plant metabolism: the uncertain fate of foliar-applied nutrients. Front Plant Sci 4:289

Fernández V, Sotiropoulos T, Brown P (2013) Foliar fertilization: scientific principles and field practices. International Fertilizer Industry Association, Paris

Foyer C, Spencer C (1986) The relationship between phosphate status and photosynthesis in leaves. Effects on intracellular orthophosphate distribution, photosynthesis and assimilate partitioning. Planta 167: 369-375

Garvin DF, Welch RM, Finley JW (2006) Historical shifts in the seed mineral micronutrient concentration of US hard red winter wheat germplasm. J Sci Food Agric 86:2213-2220

Ghosh S, Watson A, Gonzalez-Navarro OE, Ramirez-Gonzalez RH, Yanes L, Mendoza-Suárez M, Simmonds J, Wells R, Rayner T, Green P, Hafeez A, Hayta S, Melton RE, Steed A, Sarkar A, Carter J, Perkins L, Lord J, Tester M, Osbourn A, Moscou MJ, Nicholson P, Harwood W, Martin C, Domoney C, Uauy C, Hazard B, Wulff BBH, Hickey LT (2018) Speed breeding in growth chambers and glasshouses for crop breeding and model plant research. Nat Protoc 13:2944-2963. https://doi.org/10.1038/s41596-0180072-Z

Goldstein A (2014) Strategies for the development of environmentally friendly phosphate fertilizers based on gram-negative phosphate solubilizing bacteria. VFRC Report 2014/5. Virtual Fertilizer Research Center, Washington, D.C

Gonçalves RN, Pelá A, Teixeira IR (2017) Foliar phosphorus fertilization of common bean complementing phosphate fertilization at sowing. $\mathrm{J}$ Plant Nutr 40:1580-1587

GrafE, Empson KL, Eaton JW (1987) Phytic acid: a natural antioxidant. J Biol Chem 262:11647

Graham RD, Welch RM, Saunders DA, Ortiz-Monasterio I, Bouis HE, Bonierbale M (2007) Nutritious subsistence food systems. Adv Agron 92:1-74

Guttieri M, Bowen D, Dorsch JA, Raboy V, Souza E (2004) Identification and characterization of a low phytic acid wheat. Crop Sci 44:418 424

Heming SD (2007) Phosphorus balances for arable soils in Southern England 1986-1999. Soil Use Manag 23:162-170

Hitz WD, Carlson TJ, Kerr PS, Sebastian SA (2002) Biochemical and molecular characterization of a mutation that confers a decreased raffino-saccharide and phytic acid phenotype on soybean seeds. Plant Physiol 128:650-660

Huang L, Mao XY, Wang J, Chen X, Wang GH, Liao ZW (2014) The effect and mechanism of improved efficiency of physicochemical pro-release treatment for low grade phosphate rock. J Soil Sci Plant Nutr 14:316-331

Ibrahim SS, El-Midany AA, Boulos TR (2010) Effect of intensive mechanical stresses on phosphate chemistry as a way to increase its solubility for fertilizer application. Physicochem Probl Miner Process 44:79-92

IFDC (2018) Feed the future soil fertility technology (SFT) adoption, policy reform and knowledge management project. Semi-annual performance report April 1, 2018 - September 30, 2018. Cooperative agreement U.S. Agency for International Development (USAID), Washington, D.C.; International Fertilizer Development Center, Muscle Shoals, AL

Jemo M, Nwoke C, Pypers P, Vanlauwe B (2015) Response of maize (Zea mays) to the application of foliar fertilizers in the Sudan and Guinea savanna zone of Nigeria. J Plant Nutr Soil Sci 178:374-383

Jones DL, Cross P, Withers PJA, DeLuca TH, Robinson DA, Quilliam RS, Harris IM, Chadwick DR, Edwards-Jones G (2013) Review: nutrient stripping: the global disparity between food security and soil nutrient stocks. J Appl Ecol 50:851-862

Joy EJM, Ander EL, Young SD, Black CR, Watts MJ, Chilimba ADC, Chilima B, Siyame EWP, Kalimbira AA, Hurst R, Fairweather-Tait SJ, Stein AJ, Gibson RS, White PJ, Broadley MR (2014) Dietary mineral supplies in Africa. Physiol Plant 151:208-229

Khan AM, Hussain S, Rengel Z, Shah MAA (2018) Zinc bioavailability and nitrogen concentration in grains of wheat crop sprayed with zinc sulfate, ammonium sulfate, ammonium chloride, and urea. J Plant Nutr 41:1926-1936

Khande R, Sharma SK, Ramesh A, Sharma MP (2017) Zinc solubilizing Bacillus cereus and related species modulates growth, yield and zinc biofortification of soybean and wheat seeds cultivated in Central India. Rhizosphere 4:126-138

Kihara J, Sileshi GW, Nziguheba G, Kinyua M, Zingore S, Sommer R (2017) Application of secondary nutrients and micronutrients increases crop yields in sub-Saharan Africa. Agron Sustain Dev 37:25

Koele N, Kuyper TW, Bindraban PS (2014) Beneficial organisms for nutrient uptake. VFRC Report 2014/1, Virtual Fertilizer Research Center, Washington, D.C

Kottegoda N, Sandaruwan C, Priyadarshana G, Siriwardhana A, Rathnayake UA, Arachchige DMB, Kumarasinghe AR, Dahanayake D, Karunaratne V, Amaratunga GAJ (2017) Ureahydroxyapatite nanohybrids for slow release of nitrogen. ACS Nano 11:1214-1221

Kumar V, Vaiyapuri K, Amanullah MM, Gopalswamy G (2013) Influence of foliar spray of nutrients on yield and economics of soybean. J Biol Sci 13:563-565

Kumar TKMP, Mandlimath TR, Sangeetha P, Revathi SK, Kumar SKA (2018) Nanoscale materials as sorbents for nitrate and phosphate removal from water. Environ Chem Lett 16:389-400

Kumar A, Kumar V, Krishnan V, Hada A, Marathe A, Parameswaran C, Jolly M, Sachdev A (2019) Seed targeted RNAi-mediated silencing of GMMIPS1 limits phytate accumulation and improves mineral bioavailability in soybean. Sci Rep 9:7744

Kuwano M, Mimura T, Takaiwa F, Yoshida KT (2009) Generation of stable 'low phytic acid' transgenic rice through antisense repression of the 1D-myoinositol 3-phosphate synthase gene (RINO1) using the 18-kDa oleosin promoter. Plant Biotechnol J 7:96-105

Larue C, Castillo-Michel H, Sobanska S, Cecillon L, Bureau S, Barthes V, Ouerdane L, Carriere M, Sarret G (2014) Foliar exposure of the crop Lactuca sativa to silver nanoparticles: evidence for internalization and changes in Ag speciation. J Hazard Mater 264:98-106

Liu Z (2005) Grain phytic acid content in japonica rice as affected by cultivar and environment and its relation to protein content. Food Chem 89:49-52

Liu R, Lal R (2014) Synthetic apatite nanoparticles as a phosphorus fertilizer for soybean (Glycine max). Sci Rep 2014:5686 
Liu QL, Xu XH, Ren XL, Fu HW, Wu DX, Shu QY (2007) Generation and characterization of low phytic acid germplasm in rice (Oryza sativa L). Theor Appl Genet 114:803-814

Lu C, Tian H (2017) Global nitrogen and phosphorus fertilizer use for agriculture production in the past half century: shifted hot spots and nutrient imbalance. Earth Syst Sci Data 9:181-192

Ma G, Li Y, Jin Y, Zhai F, Kok FJ, Yang X (2007) Phytate intake and molar ratios of phytate to zinc, iron and calcium in the diets of people in China. Eur J Clin Nutr 61:368-374

Mayer AM (1997) Historical changes in the mineral content of fruits and vegetables. British Food J 99:207-211

McBeath TM, McLaughlin MJ, Noack SR (2011) Wheat grain yield response to and translocation of foliar-applied phosphorus. Crop Pasture Sci 62:58-65

Mogollon JM, Beusen AHW, van Grinsven HJM, Westhoek H, Bouwman AF (2018) Future agricultural phosphorus demand according to the shared socioeconomic pathways. Glob Environ Chang 50:149-163

Monasterio I, Graham RD (2000) Breeding for trace mineral in wheat. Food Nutr Bull 21:392-396

Mosali J, Desta K, Teal RK, Freeman KW, Martin KL, Lawles JW, Raun WR (2006) Effect of foliar application of phosphorus on winter wheat grain yield, phosphorus uptake, and use efficiency. J Plant Nutr 29:2147-2163

Myers SS, Zanobetti A, Kloog I, Huybers P, Leakey AD, Bloom AJ, Carlisle E, Dietterich LH, Fitzgerald G, Hasegawa T, Holbrook NM, Nelson RL, Ottman MJ, Raboy V, Sakai H, Sartor KA, Schwartz J, Seneweera S, Tausz M, Usui Y (2014) Increasing $\mathrm{CO}_{2}$ threatens human nutrition. Nature 510:139-142

Nelson DL, Lehninger AL, Cox MM (2008) Lehninger principles of biochemistry. Macmillan, London

Njoroge R, Otinga AN, Okalebo JR, Pepela M, Merckx R (2018) Maize (Zea mays L.) response to secondary and micronutrients for profitable N, P and K fertilizer use in poorly responsive soils. Agron 8:49

Noack SR, McBeath TM, McLaughlin MJ (2010) Potential for foliar phosphorus fertilisation of dryland cereal crops: a review. Crop Pasture Sci 61:659-669

Ohtake H, Tsuneda S (eds) (2019) Phosphorus recovery and recycling. Springer Nature Singapore Pte Ltd., Singapore

Ortas I, Islam KR (2018) Phosphorus fertilization impacts on corn yield and soil fertility. Commun Soil Sci Plant Anal 49:1684-1694

Pandey R, Krishnapriya V, Bindraban PS (2013) Biochemical nutrient pathways in plants applied as foliar spray: phosphorus and iron. VFRC Report 2013/1. Virtual Fertilizer Research Center, Washington DC

Pawar MW, Joshi SS, Amodkar VT (2003) Effect of foliar application of phosphorus and micronutrients on enzyme activity and juice quality in sugar cane. Sugar Technol 5:161-165

Perera I, Seneweera S, Hirotsu N (2018) Manipulating the phytic acid content of rice grain toward improving micronutrient bioavailability. Rice 11:4

Péret B, Desnos T, Jost R, Kanno S, Berkowitz O, Nussaume L (2014) Root architecture responses: in search of phosphate. Plant Physiol 166:1713-1723

Pilu R, Panzeri D, Gavazzi G, Rasmussen SK, Consonni G, Nielsen E (2003) Phenotypic, genetic and molecular characterization of a maize low phytic acid mutant (lpa241). Theor Appl Genet 107: 980-987

Punjabi M, Bharadvaja N, Jolly M, Dahuja A, Sachdev A (2018) Development and evaluation of low phytic acid soybean by siRNA triggered seed specific silencing of inositol polyphosphate 6-/3-/5-kinase gene. Front Plant Sci 9:804

Raboy V (2000) Low-phytic-acid grains. Food Nutr Bull 21:423-427

Raboy V (2009) Approaches and challenges to engineering seed phytate and total phosphorus. Plant Sci 177:281-296
Rahman M, Salleh MAM, Rashid U, Ahsan A, Hossain MM, Ra CS (2014) Production of slow release crystal fertilizer from wastewaters through struvite crystallization - a review. Arab J Chem 7:139-155

Raliya R, Tarafdar JC (2013) ZnO nanoparticle biosynthesis and its effect on phosphorous-mobilizing enzyme secretion and gum contents in clusterbean (Cyamopsis tetragonoloba L.). Agric Res 2:48-57

Raliya R, Tarafdar JC, Biswas P (2016) Enhancing the mobilization of native phosphorus in mung bean rhizosphere using $\mathrm{ZnO}$ nanoparticles synthesized by fungi. J Agric Food Chem 64:3111-3118

Rani S, Sharma A, Wali VK, Bakshi P, Bakshi M, Gupta S (2017) Effect of foliar nutrition on yield, quality and shelf-life of mango (Mangiferaindica) cv. Dashehari under Jammu sub-tropics. Indian J Agric Sci 87:185-190

Reich PB, Oleksyn J, Wright IJ (2009) Leaf phosphorus influences the photosynthesis-nitrogen relation: a cross-biome analysis of 314 species. Oecologia 160:207-212

Reich PB, Oleksyn J, Wright IJ, Niklas KJ, Hedin L, Elser JJ (2010) Evidence of a general 2/3-power law of scaling leaf nitrogen to phosphorus among major plant groups and biomes. Proc Royal Soc B-Biol Sci 277:877-883

Reijnders L (2014) Phosphorus resources, their depletion and conservation, a review. Resour Conserv Recycl 93:32-49

Rietra RPJJ, Heinen M, Dimkpa CO, Bindraban PS (2017) Effects of nutrient antagonism and synergism on yield and fertilizer use efficiency. Commun Soil Sci Plant Anal 48:1895-1920

Rockström J, Steffen W, Noone K, Persson A, Chapin FS, Lambin E, Lenton TM, Scheffer M, Folke C, Schellnhuber HJ, Nykvist B, de Wit CA, Hughes T, van der Leeuw S, Rodhe H, Sörlin S, Snyder PK, Costanza R, Svedin U, Falkenmark M, Karlberg L, Corell RW, Fabry VJ, Hansen J, Walker B, Liverman D, Richardson K, Crutzen P, Foley J (2009) Planetary boundaries: exploring the safe operating space for humanity. Ecol Soc 32:1-33

Rose TJ, Pariasca-Tanaka J, Rose MT, Fukuta Y, Wissuwa M (2010) Genotypic variation in grain phosphorus concentration, and opportunities to improve P-use efficiency in rice. Field Crop Res 119:154 160

Rowe H, Withers PJA, Baas P, Chan NI, Doody D, Holiman J, Brent J, Haigang L, Graham KM, Richard M, Andrew NS, Jianbo S, Wendy T, Matthew W, Michael NW (2016) Integrating legacy soil phosphorus into sustainable nutrient management strategies for future food, bioenergy and water security. Nutr Cycl Agroecosyst 104: 393-412

Ryan M, McInerney JK, Record IR, Angus JF (2008) Zinc bioavailability in wheat grain in relation to phosphorus fertiliser, crop sequence and mycorrhizal fungi. J Sci Food Agric 88:1208-1216

Saltzman A, Birol E, Oparinde A, Andersson MS, Asare-Marfo D, Diressie MT, Gonzalez C, Lividini K, Moursi M, Zeller M (2017) Availability, production, and consumption of crops biofortified by plant breeding: current evidence and future potential. Ann N Y Acad Sci 1390:104-114

Samavini R, Sandaruwan C, De Silva M, Priyadarshana G, Kottegoda N, Karunaratne V (2018) Effect of citric acid surface modification on solubility of hydroxyapatite nanoparticles. J Agric Food Chem 66: 3330-3337

Sattari SZ, Bouwman AF, Giller KE, van Ittersum MK (2012) Residual soil phosphorus as the missing piece in the global phosphorus crisis puzzle. PNAS 109:6348-6354

Sawan ZM, Hafez SA, Basyony AE, Alkassas AEER (2007) Cottonseed: protein, oil yields, and oil properties as influenced by potassium fertilization and foliar application of zinc and phosphorus. Grasas Aceites 58:40-48

Schlemmer U, Frølich W, Prieto RM, Grases F (2009) Phytate in foods and significance for humans: food sources, intake, processing, bioavailability, protective role and analysis. Mol Nutr Food Res 2009: S330-S375 
Schütz L, Gattinger A, Meier M, Müller A, Boller T, Mäder P, Mathimaran N (2018) Improving crop yield and nutrient use efficiency via biofertilization - a global meta-analysis. Front Plant Sci 8:2204

Shane MW, McCully ME, Lambers H (2004) Tissue and cellular phosphorus storage during development of phosphorus toxicity in Hakea prostrata (Proteaceae). J Exp Bot 55:1033-1044

Sharma S, Malhotra H, Borah P, Meena MK, Bindraban P, Chandra S, Pande V, Pandey R (2019) Foliar application of organic and inorganic iron formulation induces differential detoxification response to improve growth and biofortification in soybean. Plant Physiol Rep 24:119-128

Sharonova NL, Yapparov AK, Khisamutdinov NS, Ezhkova AM, Yapparov IA, Ezhkov VO, Degtyareva IA, Babynin EV (2015) Nanostructured water-phosphorite suspension is a new promising fertilizer. Nanotechnol Russ 10:651-661

Shukla AK, Babu PS, Tiwari PK, Prakash C, Patra AK, Patnaik MC (2015) Mapping and frequency distribution of current micronutrient deficiencies in soils in Telangana for their precise management. Indian J Fertilisers 11:33-43

Siddiqui MH, Mohammad F, Khan MN, Khan MMA (2008) Cumulative effect of soil and foliar application of nitrogen, phosphorus, and sulfur on growth, physico-biochemical parameters, yield attributes, and fatty acid composition in oil of erucic acid-free rapeseed-mustard genotypes. J Plant Nutr 31:1284-1298

Singh SK, Reddy VR, Sicher RC (2018) Seasonal critical concentration and relationships of leaf phosphorus and potassium status with biomass and yield traits of soybean. J Plant Nutr Soil Sci 181:575-585

Sistani KR, Morrill LG (1992) Foliar application of phosphorus and residual effect of gypsum on peanuts. J Environ Sci Health Part A Environ Sci Eng 27:317-327

Smil V (2000) Phosphorus in the environment: natural flows and human interferences. Annu Rev Energy Environ 25:53-88

Smit AL, Blom-Zandstra M, van der Werf A, Bindraban PS (2013) Enhancing early root growth to exploit indigenous soil $\mathrm{P}$ and fertilizer P. VFRC Report 2013/4. Virtual Fertilizer Research Center, Washington, D.C

Sohrt J, Lang F, Weiler M (2017) Quantifying components of the phosphorus cycle in temperate forests. Wiley Interdiscip Rev Water 4: e1243

Soliman AS, Hassan M, Abou-Elella F, Ahmed AHH, El-Feky SA (2016) Effect of nano and molecular phosphorus fertilizers on growth and chemical composition of baobab (Adansoniadigitata L.). J Plant Sci 11:52-60

Song OR, Lee SJ, Lee YS, Lee SC, Kim KK, Choi YL (2008) Solubilization of insoluble inorganic phosphate by Burkholderia cepacia DA23 isolated from cultivated soil. Braz J Microbiol 39: $151-156$

Srivastava G, Das CK, Das A, Singh SK, Roy M, Kim H, Sethy N, Kumar A, Sharma RK, Singh SK (2014) Seed treatment with iron pyrite (FeS2) nanoparticles increases the production of spinach. RSC Adv 4:58495-58504

Stangoulis JCR, Huynh B-L, Welch RM, Choi E-Y, Graham RD (2006) Quantitative trait loci for phytate in rice grain and their relationship with grain micronutrient content. Euphytica 154:289-294

Su D, Zhou L, Zhao Q, Pan G, Cheng F (2018) Different phosphorus supplies altered the accumulations and quantitative distributions of phytic acid, zinc, and iron in rice (Oryza sativa L.) grains. J Agric Food Chem 66:1601-1611

Talboys PJ, Heppell J, Roose T, Healey JR, Jones DL, Withers PJA (2016) Struvite: a slow-release fertiliser for sustainable phosphorus management? Plant Soil 401:109-123

Tașkın MB, Șahin Ö, Taskin H, Atakol O, Inal A, Gunes A (2018) Effect of synthetic nano-hydroxyapatite as an alternative phosphorus source on growth and phosphorus nutrition of lettuce (Lactuca sativaL.) plant. J Plant Nutr 41:1148-1154
Thompson LU, Zhang L (1991) Phytic acid and minerals: effect on early markers of risk for mammary and colon carcinogenesis. Carcinogenesis 12:2041-2045

Tian Z, Li J, He X, Jia X, Yang F, Wang Z (2017) Grain yield, dry weight and phosphorus accumulation and translocation in two rice (Oryza sativa L.) varieties as affected by salt-alkali and phosphorus. Sustainability 9:1461

Tiryakioğlu M, Yildirim M, Karanlik S (2014) Macronutrient concentration and remobilization in spring wheat organs during grain filling. Turk J Agric For 38:488-494

Ueno Y, Fujii M (2001) Three years' experience of operating and selling recovered struvite from full-scale plant. Environ Technol 22:13731381

Valkama E, Uusitalo R, Ylivainio K, Virkajärvi P, Turtol E (2009) Phosphorus fertilization: a meta-analysis of 80 years of research in Finland. Agric Ecosyst Environ 130:75-85

Van der Eijk D, Janssen BH, Oenema O (2006) Initial and residual effects of fertilizer phosphorus on soil phosphorus and maize yields on phosphorus fixing soils. Agric Ecosyst Environ 116:104-120

Van Dijk KC, Lesschen JP, Oenema O (2016) Phosphorus flows and balances of the European Union Member States. Sci Total Environ 542:1078-1093

Van Kauwenbergh J (2010) World phosphorus rock reserves and resources. International Fertilizer Development Center, Muscle Shoals

Vandamme E, Wissuwa M, Rose T, Dieng I, Drame KN, Fofana M, Senthilkumar K, Venuprasad R, Jallow D, Segda Z, Suriyagoda L, Sirisena D, Kato Y, Saito K (2016) Genotypic variation in grain P loading across diverse rice growing environments and implications for field P balances. Front Plant Sci 7:1435

Vandamme E, Kokou A, Leah M, Mujuni S, Mujawamariya G, Kamanda J, Senthilkumar K, Saito K (2018) Phosphorus micro-dosing as an entry point to sustainable intensification of rice systems in subSaharan Africa. Field Crop Res 222:39-49

Vassileva M, Serrano M, Bravo V, Jurado E, Nikolaeva I, Martos V, Vassilev N (2010) Multifunctional properties of phosphatesolubilizing microorganisms grown on agro-industrial wastes in fermentation and soil conditions. Appl Microbiol Biotechnol 85:12871299

Vengavasi K, Pandey R (2016) Root exudation index: screening organic acid exudation and phosphorus acquisition efficiency in soybean genotypes. Crop Pasture Sci 67:1096-1109

Vengavasi K, Pandey R (2018) Root exudation potential in contrasting soybean genotypes in response to low soil phosphorus availability is determined by photo-biochemical processes. Plant Physiol Biochem 124:1-9

Voogt W, Blok C, Eveleens B, Marcelis L, Bindraban PS (2013) Foliar fertilizer application - preliminary review. VFRC report 2013/2. Virtual Fertilizer Research Center, Washington, D.C.

Wakelin S, Condron L, Gerard E, Dignam BEA, Black A, O'Callaghan M (2017) Long-term P fertilisation of pasture soil did not increase soil organic matter stocks but increased microbial biomass and activity. Biol Fertil Soils 53:511-521

Wang Z, Xie X, Zhao J, Liu X, Feng W, White JC, Xing B (2012) Xylemand phloem-based transport of $\mathrm{CuO}$ nanoparticles in maize (Zea mays L). Environ Sci Technol 46:4434-4441

Wang WN, Tarafdar JC, Biswas P (2013) Nanoparticle synthesis and delivery by an aerosol route for watermelon plant foliar uptake. J Nanopart Res 15:1417

Wang Z, Liu Q, Pan F, Yuan L, Yin X (2015) Effects of increasing rates of zinc fertilization on phytic acid and phytic acid/zinc molar ratio in zinc bio-fortified wheat. Field Crop Res 184:58-64

Watts-Williams SJ, Turney TW, Patti AF, Cavagnaro TR (2014) Uptake of zinc and phosphorus by plants is affected by zinc fertilizer material and arbuscular mycorrhizas. Plant Soil 376:165-175

Welch AA, Fransen H, Jenab M et al (2009) Variation in intakes of calcium, phosphorus, magnesium, iron and potassium in 10 
countries in the European Prospective Investigation into Cancer and Nutrition study. Eur J Clin Nutr 63:S101-S121

Weldegebriel R, Araya T, Egziabher YG (2018) Effect of NPK and blended fertilizer application on nutrient uptake and use efficiency of selected sorghum (Sorghum bicolor [L] Moench) varieties under rain-fed condition in Sheraro District, Northern Ethiopia. Momona Ethiopian J Sci 10:140-156

White PJ, Broadley MR (2005) Historical variation in the mineral composition of edible horticultural products. J Hortic Sci Biotechnol 80: 660-667

WHO (1996) Trace elements in human nutrition and health. World Health Organisation, Geneva

Withers PJA, Sylvester-Bradley R, Jones DL, Healey JR, Talboys PJ (2014) Feed the crop not the soil: rethinking phosphorus management in the food chain. Environ Sci Technol 48:6523-6530

Wojcik P, Wojcik M (2007) Response of mature phosphorus-deficient apple trees to phosphorus fertilization and liming. J Plant Nutr 30: $1623-1637$

Xia H, Xue Y, Liu D, Kong W, Xue Y, Tang Y, Li J, Li D, Mei P (2018) Rational application of fertilizer nitrogen to soil in combination with foliar $\mathrm{Zn}$ spraying improved $\mathrm{Zn}$ nutritional quality of wheat grains. Front Plant Sci 9:677

Xie X, Li R, Zhang Y, Shen S, Bao Y (2018) Effect of elevated $\left[\mathrm{CO}_{2}\right]$ on assimilation, allocation of nitrogen and phosphorus by maize (Zea mays L.). Commun Soil Sci Plant Anal 49:1032-1044

Yadav LR, Choudhary GL (2012) Effect of fertility levels and foliar nutrition on profitability, nutrient content and uptake of cowpea [Vigna unguiculata (L.) Walp]. Legum Res 35:258-260
Yosefi K, Galavi M, Ramrodi M, Mousavi SR (2011) Effect of biophosphate and chemical phosphorus fertilizer accompanied with micronutrient foliar application on growth, yield and yield components of maize (Single Cross 704). Aust J Crop Sci 5:175-180

Zahra Z, Arshad M, Rafique R, Mahmood A, Habib A, Qazi IA, Khan SA (2015) Metallic nanoparticle (TiO2 and Fe3O4) application modifies rhizosphere phosphorus availability and uptake by Lactuca sativa. J Agric Food Chem 63:6876-6882

Zhang YQ, Yi XS, You LY, Karim R, Yan FX, Peng Y, Qing FM, Zhen LC, Cakmak I, Zhang FS, Zou CQ (2012) Zinc biofortification of wheat through fertilizer application in different parts of China. Field Crop Res 125:1-7

Zhang W, Liu D, Li C, Chen X, Zou C (2017a) Accumulation, partitioning, and bioavailability of micronutrients in summer maize as affected by phosphorus supply. Eur J Agron 86:48-59

Zhang W, Liu D, Liu Y, Chen X, Zou C (2017b) Overuse of phosphorus fertilizer reduces the grain and flour protein contents and zinc bioavailability of winter wheat (Triticum aestivum L.). J Agric Food Chem 65:1473-1482

Zhu J, Li M, Whelan M (2018) Phosphorus activators contribute to legacy phosphorus availability in agricultural soils: a review. Sci Total Environ 62:522-537

Publisher's note Springer Nature remains neutral with regard to jurisdictional claims in published maps and institutional affiliations. 